\title{
Interkinetic and Migratory Behavior of a Cohort of Neocortical Neurons Arising in the Early Embryonic Murine Cerebral Wall
}

\author{
Takao Takahashi, ${ }^{1}$ Richard S. Nowakowski, ${ }^{2}$ and Verne S. Caviness Jr. ${ }^{1}$ \\ ${ }^{1}$ Department of Neurology, Massachusetts General Hospital, Harvard Medical School, Boston, Massachusetts 02114, \\ ${ }^{2}$ Department of Pediatrics, Keio University School of Medicine, Tokyo 160, Japan, and ${ }^{3}$ Department of Neuroscience and \\ Cell Biology, University of Medicine and Dentistry of New Jersey-Robert Wood Johnson Medical School, Piscataway, \\ New Jersey 08854
}

\begin{abstract}
Neocortical neuronogenesis occurs in the pseudostratified ventricular epithelium (PVE) where nuclei of proliferative cells undergo interkinetic nuclear movement. A fraction of daughter cells exits the cell cycle as neurons (the quiescent, or $\mathrm{Q}$, fraction), whereas a complementary fraction remains in the cell cycle (the proliferative, or $\mathrm{P}$, fraction). By means of sequential thymidine and bromodeoxyuridine injections in mouse on embryonic day 14 , we have monitored the proliferative and postmitotic migratory behaviors of 1 and 2 hr cohorts of PVE cells defined by the injection protocols. Soon after mitosis, the $\mathrm{Q}$ fraction partitions into a rapidly exiting (up to $50 \mu \mathrm{m} / \mathrm{hr}$ ) subpopulation $\left(Q_{r}\right)$ and a more slowly exiting $(6 \mu \mathrm{m} / \mathrm{hr})$ subpopu-
\end{abstract}

lation $\left(Q_{\mathrm{s}}\right) \cdot Q_{\mathrm{r}}$ and $Q_{\mathrm{s}}$ are separated as two distributions on exit from the ventricular zone with an interpeak distance of $\sim 40 \mu \mathrm{m}$. Cells in $Q_{r}$ and $Q_{s}$ migrate through the intermediate zone with no significant change in the interpeak distance, suggesting that they migrate at approximately the same velocities. The rate of migration increases with ascent through the intermediate zone (average 2-6.4 $\mathrm{m} / \mathrm{hr}$ ) slowing only transiently on entry into the developing cortex. Within the cortex, $Q_{\mathrm{r}}$ and $Q_{\mathrm{s}}$ merge to form a single distribution most concentrated over layer $\mathrm{V}$.

Key words: neocortical neuronogenesis; cell cycle; proliferation; neuronal migration; mouse; ventricular zone
The majority of, and perhaps all, neurons of the neocortex arise in a proliferative pseudostratified ventricular epithelium (PVE), which forms the ventricular lining of the developing cerebral wall (for review, see Takahashi et al., 1995a). The nucleus of a proliferative cell undergoes interkinetic movement as the cell traverses the cell cycle. During $M$ and at the outset of G1, the nucleus is located at the ventricular surface; it then ascends to the outer margin of the epithelium where $\mathrm{S}$ phase is initiated. The nucleus then descends toward the ventricle in the course of S and G2 phases (Fig. 1).

After mitosis, a fraction of the postmitotic cells exits the cell cycle (quiescent, or Q, fraction), whereas a complementary fraction re-enters $\mathrm{S}$ phase and sustains the proliferative pool (proliferative, or $\mathrm{P}$, fraction) $(P=1-\mathrm{Q})$ (Takahashi et al., 1994, 1996). $\mathrm{Q}$ fraction cells exit the epithelium and migrate across the developing cerebral wall to enter the cortex where the earliest formed cells take up positions in the deepest cortical layers. Later formed cells are distributed to progressively more superficial cortical layers (Sidman et al., 1959; Berry and Rogers, 1965; Hicks and D'Amato, 1968; Sidman and Rakic, 1973; Fernandez and Bravo, 1974; Rakic, 1974; Bisconte and Marty, 1975; Caviness, 1982; Luskin and Shatz, 1985; Bayer and Altman, 1991). Neither the appearance of the proliferating cells nor their immediate behavior after their terminal mitosis presages the varied forms (e.g., pyramidal or stellate) and functional attributes (e.g., excitatory or

Received April 16, 1996; revised June 28, 1996; accepted July 2, 1996.

This work was supported by National Institutes of Health Grants NS12005 and NS28061 and NASA Grant NAG2-950. T.T. was supported by a fellowship of the Medical Foundation, Inc., Charles A. King Trust, Boston, MA. Valuable discussions with Pradeep Bhide and Sahoko Miyama are gratefully acknowledged.

Correspondence should be addressed to Dr. T. Takahashi, Department of Neurology, Massachusetts General Hospital, 25 Fruit Street, Boston, MA 02114.

Copyright (C) 1996 Society for Neuroscience $0270-6474 / 96 / 165762-15 \$ 05.00 / 0$ inhibitory, projection, or interneuronal) that will be characteristic of the mature neocortical cells (Sidman et al., 1959; Sidman and Rakic, 1973; Berry and Rogers, 1965; Hicks and D'Amato, 1968; Fernandez and Bravo, 1974; Rakic, 1974; Bisconte and Marty, 1975; Caviness, 1982; Luskin and Shatz, 1985; Bayer and Altman, 1991).

We have previously determined the length of the cell cycle $\left(T_{\mathrm{c}}\right)$ and its phases (Takahashi et al., 1992, 1993, 1995a) and the values for Q and P fractions (Takahashi et al., 1994, 1996) in the PVE of the dorsomedial cerebral wall for the entire neuronogenetic interval in mice. These parameters support a neuronogenetic model that predicts the rate of neuron production and the total number of neurons that will be produced. The present analysis was conducted on embryonic day 14 (E14), which is in the course of the seventh and eighth cell cycles $\left(\mathrm{CC}_{7-8}\right)$ of the total of 11 integer cell cycles that make up the neuronogenetic interval (Takahashi et al., 1995a). By tracking the proliferative and postproliferative behavior of small cohorts of PVE cells defined by sequential injections of two S-phase markers, we estimate the rates of interkinetic nuclear movement of the $\mathrm{P}$ fraction and the exit velocities of the $\mathrm{Q}$ fraction. We then track the migratory behavior of the $\mathrm{Q}$ fraction and afterward its postmigratory fate within the cortex, including an estimate of the relative contributions of cell death and tissue growth to population dilution. The analysis thus chronicles, with high spatial and temporal precision, the principal events of cortical histogenesis for strictly defined cell populations.

\section{MATERIALS AND METHODS}

General methods. Procedures involving animals and histological procedures have been presented elsewhere in detail (Takahashi et al., 1992, 1993, 1994), and will be reviewed here only in outline. CD1 mice were maintained on a $12 \mathrm{hr}$ (7:00 A.M. to 7:00 P.M.) light/dark schedule. Conception was ascertained by the presence of a vaginal plug with the day 


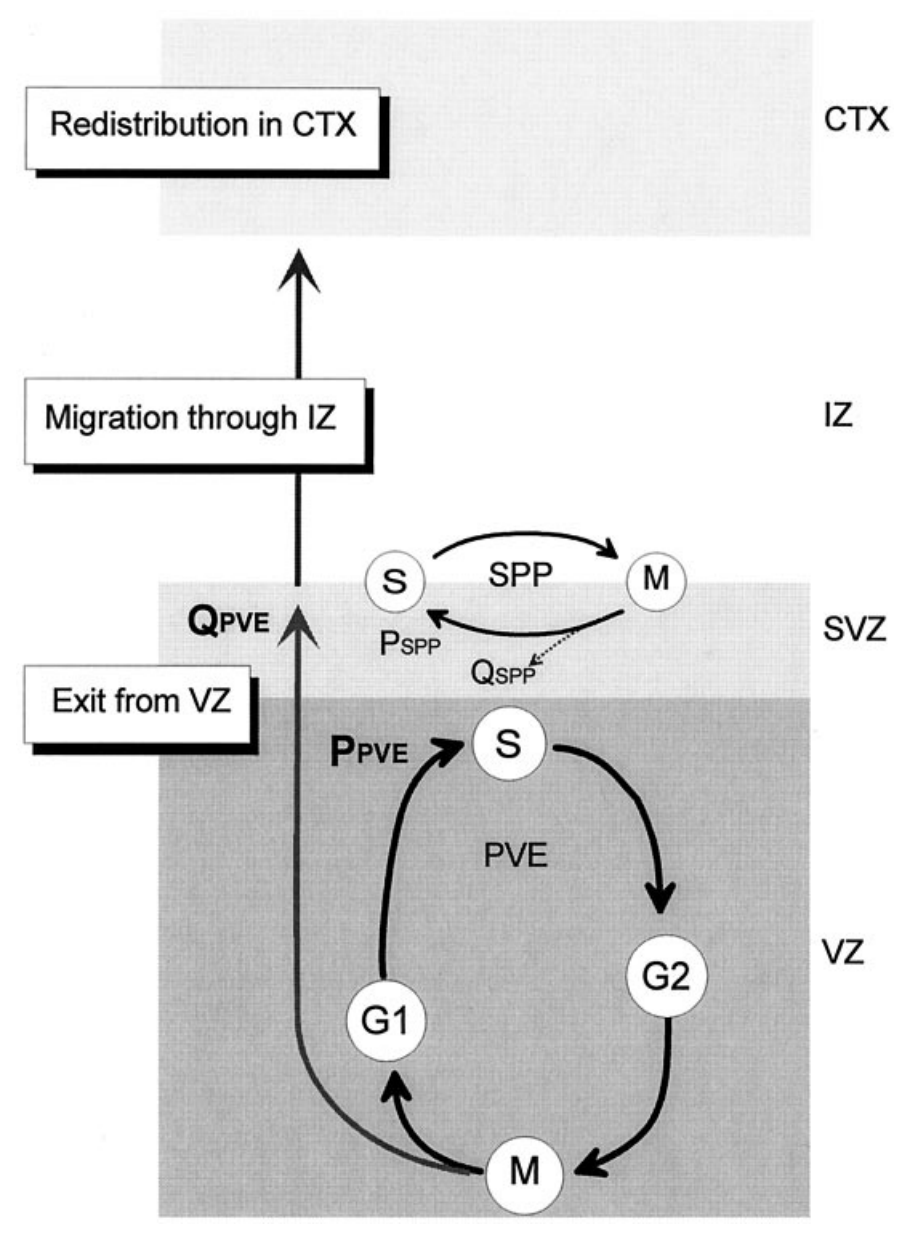

Figure 1. Neocortical histogenesis: the sequence of cellular events. Histogenesis is initiated with cell proliferation in the pseudostratified ventricular epithelium $(P V E)$, which is approximately coextensive with the ventricular zone $(V Z)$ lying at the ventricular margin. $\mathrm{P}$ fraction cells of the PVE $\left(P_{P V E}\right)$ undergo interkinetic nuclear migration as they progress through the G1-to-S-to-G2-to-M phases of the cell cycle. Q fraction cells of the PVE $\left(Q_{P V E}\right)$ exit the VZ and migrate through the subventricular zone $(S V Z)$ and intermediate zone (IZ) to the developing cortex $(C T X)$. The earliest formed neurons take up positions in the deepest cortical layers, whereas cells formed progressively later are distributed to progressively more superficial cortical layers (Redistribution in CTX). The secondary proliferative population $(S P P)$, thought to be the progenitor population for glial cells, arises from the PVE. Its cells become distributed through a broad zone spanning the outer VZ, SVZ, and IZ. Cells of the SPP do not undergo interkinetic nuclear migration.

of conception considered to be E0. Plug checks were conducted at 9:00 A.M. The experiments are based on double labeling with the S-phase markers tritiated thymidine $\left[{ }^{3} \mathrm{H}\right] \mathrm{TdR}(5 \mu \mathrm{Ci} / \mathrm{gm}$ body weight $)$ and the thymidine analog bromodeoxyuridine (BUdR) $(50 \mu \mathrm{g} / \mathrm{gm}$ body weight) (Sigma, St. Louis, MO) injected intraperitoneally into pregnant dams. Embryos were removed by hysterotomy from dams deeply anesthetized by an intraperitoneal injection of a mixture of ketamine $(50 \mathrm{mg} / \mathrm{kg}$ body weight) and xylazine (10 mg/kg body weight). The embryos were decapitated, and the whole heads were fixed in $70 \%$ ethanol, dehydrated, embedded in paraffin, and sectioned at $4 \mu \mathrm{m}$ in the coronal plane. The sections were stained immunohistochemically for BUdR using DAB as a chromogen without color intensification. After immunocytochemistry, the slides were dipped in Kodak NTB2 nuclear emulsion (Eastman Kodak, Rochester, NY) and kept at $4^{\circ} \mathrm{C}$ for 6 weeks. They were developed with D-19, fixed with Ektaflo, and counterstained with $0.1 \%$ basic fuchsin.

S-phase labeling sequences to define cell cohorts. Proliferative cells in the PVE of the developing forebrain cycle asynchronously. Cohorts of proliferative cells of the PVE, which exit S phase over either a 1 or $2 \mathrm{hr}$ interval, referred to as a $1 \mathrm{hr}$ cohort or a $2 \mathrm{hr}$ cohort, were identified by an S-phase labeling schedule based on sequential exposure to $\left[{ }^{3} \mathrm{H}\right] \mathrm{TdR}$ and BUdR (for details, see legend to Fig. 2) (Takahashi et al., 1994) (our unpublished observations).

Experiments based on the $1 \mathrm{hr}$ cohort are designed as a survey of nuclear movement of cycling cells (cells of the P fraction) and cells that exit the cycle (cells of the $\mathrm{Q}$ fraction). The progression of nuclei of cells of the $1 \mathrm{hr}$ cohort is followed at $0.5,3.5,5.0,6.5,8.0$, and $12.5 \mathrm{hr}$ after exposure to BUdR. For the $1 \mathrm{hr}$ cohort followed only to the $8.0 \mathrm{hr}$ time point, there was only a single exposure to BUdR. The post-BUdR interval through $8.0 \mathrm{hr}$ is less than $T_{\mathrm{c}}$ minus the length of S phase $\left(T_{\mathrm{C}}-T_{\mathrm{S}}, 11.3\right.$ $\mathrm{hr}$ on E14) (Takahashi et al., 1995a). Therefore, through the 8.0 time point, $\left[{ }^{3} \mathrm{H}\right] \mathrm{TdR}$-only labeled cells of the $1 \mathrm{hr}$ cohort represent both the $\mathrm{P}$ and $\mathrm{Q}$ fractions of the original cohort.

For the $12.5 \mathrm{hr}$ time point involving the $1 \mathrm{hr}$ cohort, four BUdR injections were given in addition to the single injection given for the time points through $8.0 \mathrm{hr}$. These were given at $3.0 \mathrm{hr}$ intervals, with the last given $0.5 \mathrm{hr}$ before embryo harvest. The $12.5 \mathrm{hr}$ time point occurs at an interval after exposure to BUdR, which is more than $T_{\mathrm{C}}-$ $T_{\mathrm{S}}$, by which time all $\mathrm{P}$ fraction cells of the original cohort will have been labeled with BUdR as they re-entered $\mathrm{S}$ phase. Therefore, $\left[{ }^{3} \mathrm{H}\right] \mathrm{TdR}$-only labeled cells represent only the $\mathrm{Q}$ fraction of the original cohort (Takahashi et al., 1994; 1996).

Experiments based on the $2 \mathrm{hr}$ cohort are designed to track nuclear progression of the $\mathrm{Q}$ fraction of cells in the course of their migrations to the cortex and, after their migrations are completed, as they become redistributed within the cortex (Figs. 1, 2). The Q fraction at E14 is 0.37 (Takahashi et al., 1994). Thus, it is to be expected that only $37 \%$ of the cohort labeled by this protocol will exit the cell cycle. To label a larger contingent of cells that could be followed as they migrate to the cortex, the delay between $\left[{ }^{3} \mathrm{H}\right] \mathrm{TdR}$ and BUdR injections was increased to $2 \mathrm{hr}$; that is, migrations were followed in a $2 \mathrm{hr}$ rather than a $1 \mathrm{hr}$ cohort. As with animals at the $12.5 \mathrm{hr}$ time point of the $1 \mathrm{hr}$ cohort, for each set of animals for the $2 \mathrm{hr}$ cohorts, an additional four BUdR injections were given to distinguish the $\mathrm{Q}$ fraction from the $\mathrm{P}$ fraction. The progression of the Q fraction only of the $2 \mathrm{hr}$ cohort is followed from the $12.5 \mathrm{hr}$ time point through staged time points in the course of migrations $(24,36,48$, $60 \mathrm{hr}$ after BUdR exposure at 9:00 A.M. on E14) and into the postmigration interval [postnatal day 4 (P4) and P22] (day of birth, P0).

The analysis was undertaken in a "standard sector" of the dorsomedial cerebral wall corresponding to the posterior medial region of the future first somatosensory representation (Takahashi et al., 1992). For the embryonic time points, where the focus was on the position of nuclei within the ventricular zone (VZ) and while migrating across the cerebral wall, the size of the sector was defined with respect to the ventricular surface, where it was $100 \mu \mathrm{m}$ in its medial-to-lateral dimension of the coronal section and $4 \mu \mathrm{m}$ in depth, corresponding to section thickness. For analysis of the postmigratory intracortical positions of labeled nuclei in postnatal animals, the size of the sector was defined with respect to the cortical surface, where again it was $100 \mu \mathrm{m}$ in its medial-to-lateral dimension of the coronal section and $4 \mu \mathrm{m}$ in depth, corresponding to section thickness. For analysis of positions of nuclei of cells of both the 1 and $2 \mathrm{hr}$ cohorts, the sectors of the cerebral wall were divided into bins, $10 \mu \mathrm{m}$ in height. The bins were numbered $1,2,3$, and so on, from the ventricular surface outward (Takahashi et al., 1992) for the embryonic time points and from the pial surface inward for the postnatal time points. For both $1 \mathrm{hr}$ and $2 \mathrm{hr}$ cohorts, experimental time points are based on analysis of brains of eight animals, four from each of two different litters, and eight nonadjacent sections were analyzed for each brain.

Mathematical analysis. The distribution of cells per bin was computed by first averaging the values obtained from eight nonadjacent sections from single brains and then by averaging the values obtained from eight brains. Then, when necessary, a separation of populations was calculated by using a least-squares fit of two (or more) normal distributions to a bimodal (or multimodal) histogram. This method provided an objective and unbiased estimate of the size and mean position of separate populations, regardless of whether there was overlap in their distributions. All calculations were performed with Microsoft Excel.

\section{RESULTS}

The analysis spans an interval beginning in the morning of E14 continuing through P22 and follows a small proportion of the cells that are "born" during the cell cycle that is initiated early on the morning of E14. Figure 3 illustrates the dramatic growth of the 
Figure 2. Protocols for defining 1 and 2 hr cell cohorts. Proliferating cells of the PVE are first exposed to $\left[{ }^{3} \mathrm{H}\right] \mathrm{TdR}$ (arrowhead with dots) either at 7:00 A.M. (2 hr cohort) or at 8:00 A.M. (1 hr cohort) on E14. All (and only) proliferating cells that are in $\mathrm{S}$ phase incorporate the marker (white nuclei with dots). At 9:00 A.M., which is either $1 \mathrm{hr}(1 \mathrm{hr}$ cohort $)$ or $2 \mathrm{hr}$ (2 hr cohort) after exposure to $\left[{ }^{3} \mathrm{H}\right] \mathrm{TdR}$, the PVE is exposed to BUdR (solid arrowhead). This second marker will be incorporated by cells that already contain $\left[{ }^{3} \mathrm{H}\right] \mathrm{TdR}$ and are still in S phase (gray-filled nuclei with dots) and also by cells that have entered $\mathrm{S}$ phase subsequent to the $\left[{ }^{3} \mathrm{H}\right] \mathrm{TdR}$ exposure (gray-filled nuclei without dots). Thus, the cells that leave $\mathrm{S}$ phase between the $\left[{ }^{3} \mathrm{H}\right] \mathrm{TdR}$ and BUdR exposures (i.e., between 8:00 A.M. and 9:00 A.M. for the $1 \mathrm{hr}$ cohort or between 7:00 A.M. and 9:00 A.M. for the $2 \mathrm{hr}$ cohort) will be marked only by $\left[{ }^{3} \mathrm{H}\right] \mathrm{TdR}$ (asterisks), and it is these $\left[{ }^{3} \mathrm{H}\right]$ TdR-only labeled cells that are referred to as the 1 and $2 \mathrm{hr}$ cohorts of cells. For the $1 \mathrm{hr}$ cohort where the experimental interval is $\leq 8.0 \mathrm{hr}$, there is only the single exposure to BUdR. For the $1 \mathrm{hr}$ cohort where the experimental interval is $12.5 \mathrm{hr}$ and for all time points for the $2 \mathrm{hr}$ cohort, the exposure to BUDR is repeated every $3 \mathrm{hr}$ (open arrowheads) through an interval corresponding to the length of the cell cycle minus the length of $\mathrm{S}$ phase $\left(T_{\mathrm{C}}-T_{\mathrm{S}}\right)$ to double label the $\mathrm{P}$ fraction cells of the cohort after they reenter $\mathrm{S}$ phase. The leading edge of the 1 and $2 \mathrm{hr}$ cohorts corresponds to the cells that leave $\mathrm{S}$ phase immediately after exposure to $\left[{ }^{3} \mathrm{H}\right] \mathrm{TdR}$, whereas the trailing edge corresponds to the last cells to leave $\mathrm{S}$ phase before BUdR exposure. The 1 and 2 hr cohorts of cells advance through G2 and $\mathrm{M}$ phases as a coherent wave. After mitosis, the daughter cells partition into Q (exiting cell cycle) and $\mathrm{P}$ (re-entering $\mathrm{S}$ phase) subsets of the original cohort. The progression of the $\mathrm{Q}$ fraction is followed as it exits the VZ (Exit from $V Z$ ) and migrates across the IZ (Migration through IZ) at $12.5-60 \mathrm{hr}$ to reach the cortex $(C T X)$. The $\mathrm{Q}$ fraction is followed further at $\mathrm{P} 4$ and P22 within the cortex, where it will be positioned above cells that migrated before and below cells that migrated afterward (Redistribution in CTX).

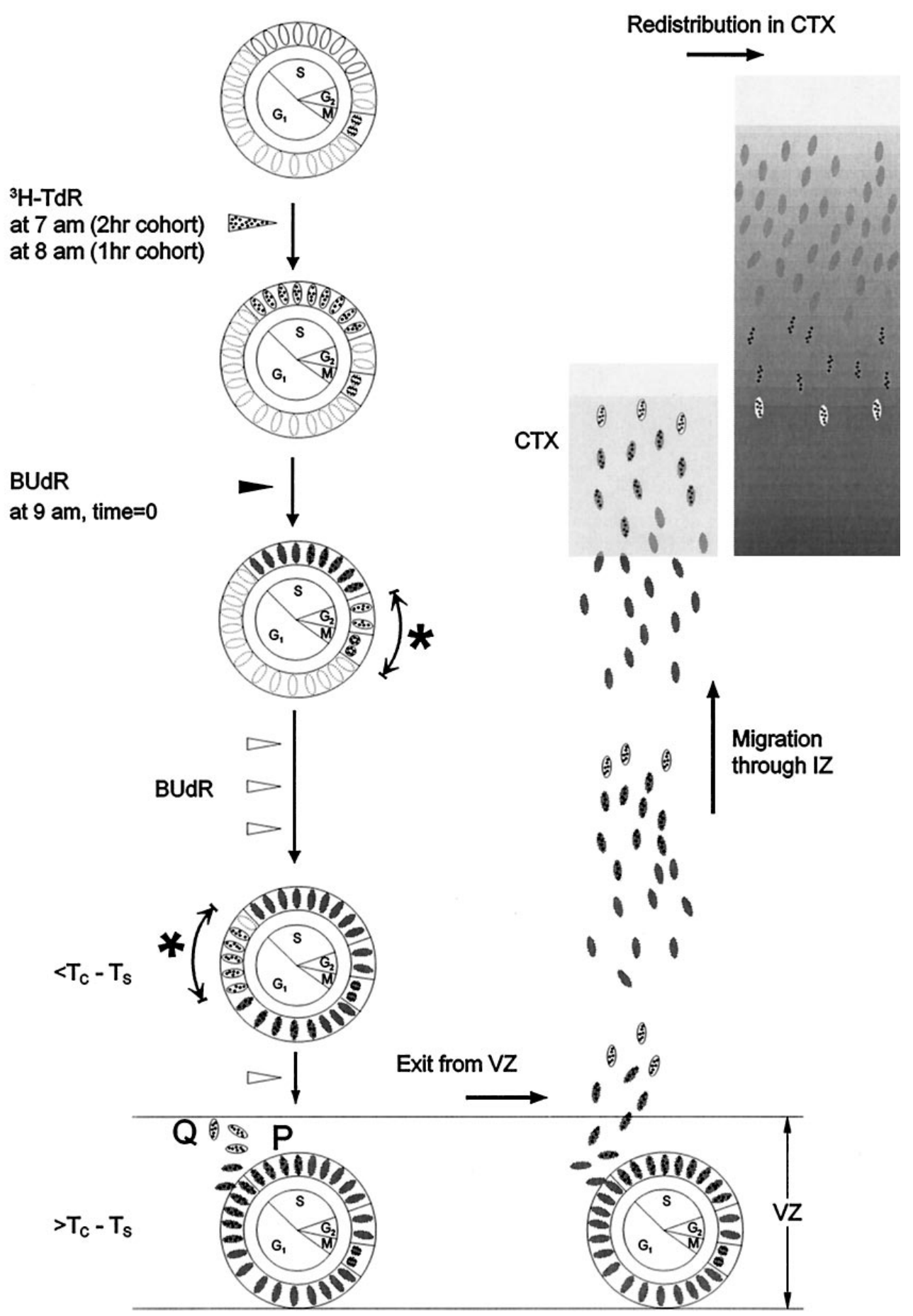

cerebral wall and the changes in the pattern of its stratification that occur over the first few days of this interval (Takahashi et al., 1995a). At 9:00 A.M. on E14 (the $0 \mathrm{hr}$ time point in this study), the dorsomedial cerebral wall is bilaminate, comprised only of the VZ, corresponding approximately to the PVE, and the overlying primitive plexiform zone (PPZ). In the course of the afternoon on E14, the embryonic cortical strata, molecular layer (ML), cortical plate (CP) and subplate (SP), emerge in the PPZ; concurrently, the intermediate zone (IZ) becomes established between cortical strata and the VZ (Takahashi et al., 1993). Between E15 and E17, the $\mathrm{CP}$ increases severalfold in thickness, and toward the end of this period, the VZ regresses and then disappears. By P4, the SP, the deepest cortical stratum, and corresponding at this age to neocortical layers V and VI of the mature cortex, already has begun to acquire the cytoarchitectonic appearance of layers $\mathrm{V}$ and VI. The packing density of cells in the outer half of the $\mathrm{CP}$ already is less than that in its inner half, anticipating the emergence of neocortical layer IV in the inner half and layers II/III in the outer half of the CP. By P22, all cortical layers have attained their mature cytoarchitectonic features.

The advance in complexity of stratification of the cerebral wall beyond the morning of E14 is paralleled by a dramatic accelera- 


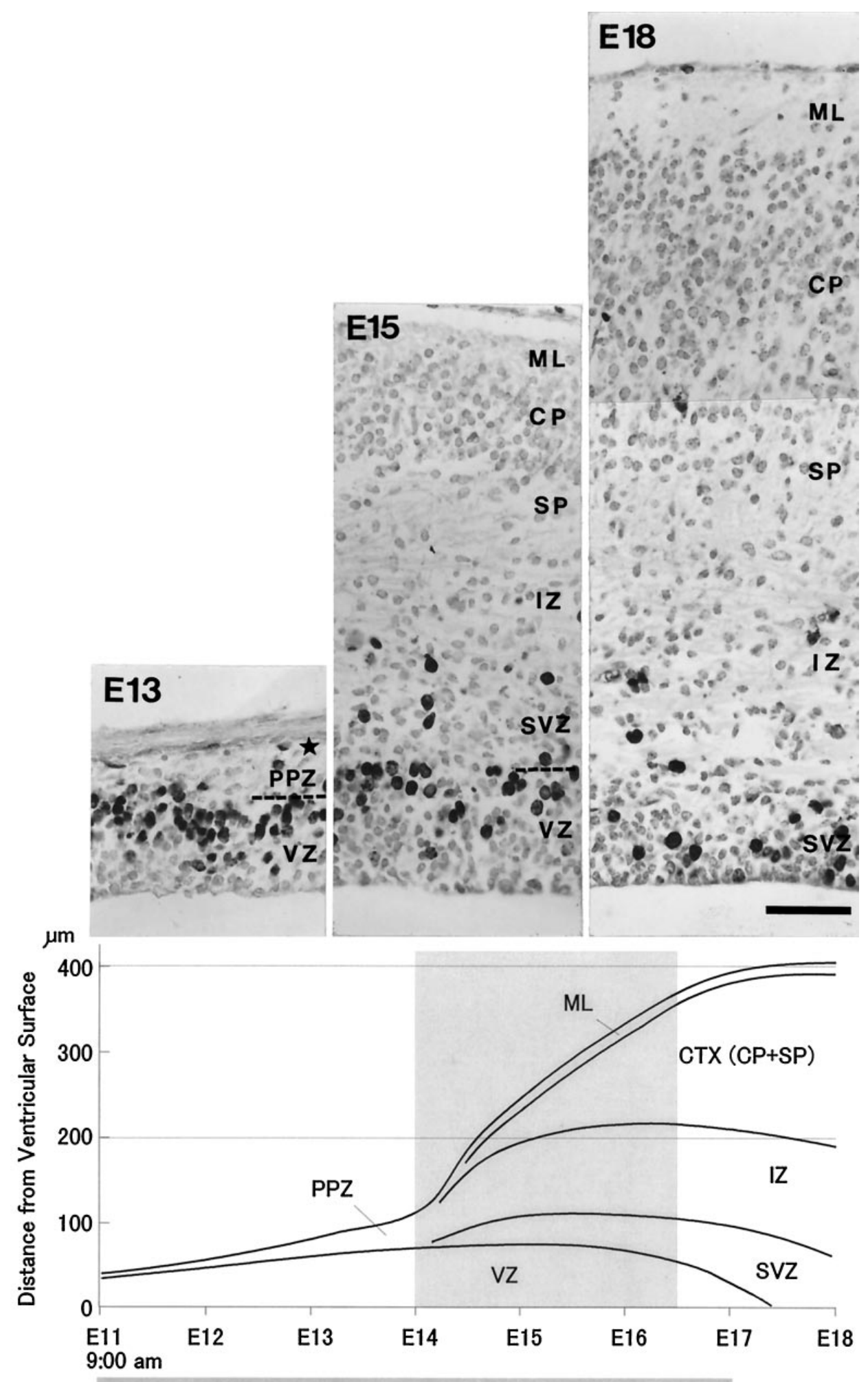

Neuronogenetic Interval
Figure 3. Strata of the murine dorsomedial cerebral wall during the experimental interval (modified from Takahashi et al., 1995a). One and two hour cohorts of cells were established by sequential $\left[{ }^{3} \mathrm{H}\right] \mathrm{TdR}$ - and BUdR-labeling protocols (Fig. 2) on E14, $3 \mathrm{~d}$ after the onset of the neuronogenetic interval that extends in mouse from early E11 through early E17 (gray bar at the base of the graph) (Takahashi et al., 1995a). The movements of the cohorts were tracked from E14 through E16 in the course of their migrations (shaded area) and also postnatally at P4 and P22 (day of birth, P0). The heights of the cerebral strata were determined by direct measurements in histological sections (Takahashi et al., 1995a). From E11 through early E14, the cerebral wall is principally the $\mathrm{VZ}$ with narrow overlying primitive plexiform zone (PPZ). On E14, the SVZ, IZ, and cortical strata [subplate (SP), cortical plate (CP), and molecular layer (ML)] replace the PPZ. The ventricular surface corresponds to 0 on the $y$-axis. The pial surface is the outer limit of the ML. The contours tracing progressive growth of strata were made initially by a least-squares fit to a fourth order curve and then smoothed by eye. Three photomicrographic inserts depict the principal histological features of the dramatic transitions that occur in the cerebral strata over the neuronogenetic interval. Each is taken from a $4-\mu$ m-thick coronal section stained immunocytochemically for BUdR and counterstained with basic fuchsin. The embryos had been exposed to BUdR only 30 min before killing so that the distribution of black, BUdR-positive nuclei corresponds to the zone of $\mathrm{S}$ phase at each illustrated age. Insert E13 is representative of the cerebral wall when the strata include only $\mathrm{VZ}$ and PPZ. A star marks the pia. Insert E15 represents the cerebral wall relatively late in the course of neuronogenesis when the full stratification plan is established, and insert E18 represents the cerebral wall after the neuronogenetic interval is completed. The S-phase zone at E13 and E15 corresponds principally to the outer half of the VZ, although with some S-phase activity in cells of the SPP in the SVZ and IZ at E15. The increase in the width of the cerebral wall between E15 and E18 largely represents increase in width of the cortical strata. By E18, the VZ has become reduced to a simple cuboidal epithelium, and S-phase activity is limited to cuboidal ependymal cells and the SPP. Scale bar, $50 \mu \mathrm{m}$. tion in its rate of growth (Fig. 3). Thus, the dorsomedial cerebral wall more than doubles in width over the first $24 \mathrm{hr}$ of the experimental interval (9:00 A.M. on E14 through 9:00 A.M. on E15) before its rate of growth slows. Nested within the overall pattern of growth of the cerebral wall are accelerations and subsequent decelerations in the rate of growth of the separate strata. Over the $12 \mathrm{hr}$ after the morning of E14, as the full stratification plan of the cerebral wall is becoming established, growth is dominant in the IZ, which increases twofold in width in this interval. The growth of the IZ then almost ceases on E15, whereas that of the cortical strata advances. The VZ, in the depths of the cerebral wall, already has reached its maximum width by 
Figure 4. Distribution of $1 \mathrm{hr}$ cohort of $\left[{ }^{3} \mathrm{H}\right] \mathrm{TdR}$-only labeled cells in relation to the distribution of cells in $\mathrm{S}$ phase at E14. The photomicrograph (left) illustrates an example of cells of the $1 \mathrm{hr}$ cohort $\left(\left[{ }^{3} \mathrm{H}\right] \mathrm{TdR}\right.$-only labeled cells) located both in the VZ (small arrows) and above the VZ (arrowhead). Also illustrated are S-phase cells labeled with BUdR (darkly stained nuclei) in the S-phase zone. Right, The number of cells of the cohort per $10 \mu \mathrm{m}$ bin (see Materials and Methods) is plotted as histograms. Those within the VZ concentrated in bins 1-2 (filled bars, inner subset) belong to the PVE. A smaller number of cells of the cohort above the VZ (unfilled bars, outer subset) belongs to the SPP. Superimposed on the histogram is a broken line reflecting the BUdRlabeling index, as obtained from the sections that were labeled with BUdR 30 min before killing. BUdR-labeled cells in $\mathrm{S}$ phase are most concentrated in the outer half of the VZ (S-phase zone) (see also Takahashi et al., 1993).

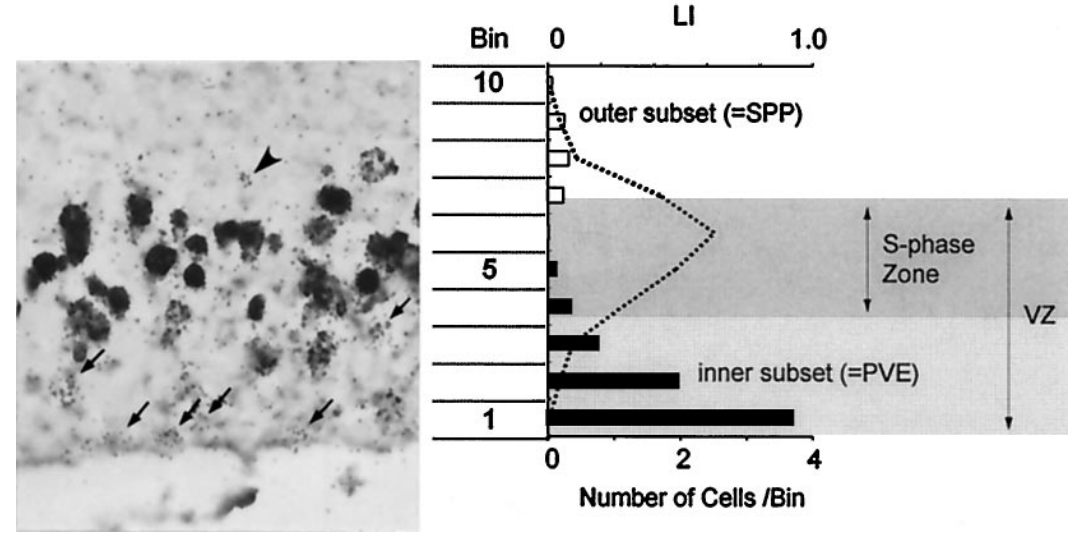

E15, as growth of overlying strata accelerates. Beyond E16, the $\mathrm{VZ}$ becomes reduced in width, and by E18, after exhaustion of the PVE, the VZ is replaced by a simple cuboidal ventricular lining. The subventricular zone (SVZ), on the other hand, follows a growth cycle more like that of the cortical strata, with a phase of acceleration beginning after E14 and continuing until E17-E18.

\section{Interkinetic nuclear migration}

\section{Before mitosis}

The $1 \mathrm{hr}$ cohort is defined by exposure to [ $\left.{ }^{3} \mathrm{H}\right] \mathrm{TdR}$ followed in 1 hr by exposure to BUdR. Cells of the cohort, labeled by $\left[{ }^{3} \mathrm{H}\right] \mathrm{TdR}$ only, will have exited S phase to enter G2 phase continuously over the hour separating the two injections (see legend for Fig. 2). At the time of the first time point in these experiments, taken $0.5 \mathrm{hr}$ after the BUdR injection, the leading edge of the cohort $(1.5 \mathrm{hr}$ after exit from $\mathrm{S}$ ) will have advanced to prophase (the combined length of $\mathrm{G} 2$ and $\mathrm{M}=2 \mathrm{hr}$ ) (Takahashi et al., 1993). The trailing edge ( $0.5 \mathrm{hr}$ after exit from S) would be in G2 phase. Appropriately, as shown in Figure 4, at the $0.5 \mathrm{hr}$ time point after the BUdR injection, the nuclei of cells of the cohort are distributed bimodally. As estimated from the histogram, the majority of the nuclei, i.e., 6.75 per sector or $88 \%$ of the $\left[{ }^{3} \mathrm{H}\right] \mathrm{TdR}$-only labeled cells (Table 1, rows 2,3 ) are concentrated in a narrow zone within the inner half of the VZ (mostly in bins 1 and 2) (Fig. 4). This inner subset corresponds to cells of the PVE in G2 or prophase, which have shifted inward toward the ventricular surface as a result of interkinetic nuclear migration (Fig. 1). A small proportion of the labeled nuclei, i.e., 0.94 per sector or $12 \%$ of the total (Table 1, rows 2,3) are concentrated in a zone that spreads from the outer margin of the VZ into the overlying PPZ (mostly in bins 7-9) (Fig. 4). This outer subset of nuclei belongs to cells of the secondary proliferative population (SPP) (Takahashi et al., 1995b) which, like those of the inner subset, are in G2 phase or prophase. Because $T_{\mathrm{C}}$ for both PVE and SPP on E14 are identical at $\sim 15 \mathrm{hr}$, the relative proportions of the labeled nuclei in the PVE and SPP subsets correspond to the relative sizes of the total PVE and SPP populations on E14 (Takahashi et al., 1995b).

\section{After mitosis}

\section{Distribution of the $1 \mathrm{hr}$ cohort}

An example of the distribution of the $1 \mathrm{hr}$ cohort at the $6.5 \mathrm{hr}$ time point is shown in Figure 5, and histograms of the distributions of the nuclei of the $1 \mathrm{hr}$ cohort at the 3.5, 5.0, 6.5, and $8.0 \mathrm{hr}$ time points are shown in Figure 6 . As at the $0.5 \mathrm{hr}$ time point, the distribution of the labeled nuclei at the $3.5 \mathrm{hr}$ time point (trailing edge of the $1 \mathrm{hr}$ cohort $3.5 \mathrm{hr}$ after exit from $\mathrm{S}$ or $1.5 \mathrm{hr}$ after mitosis) is bimodal (Fig. 6). The majority of the labeled nuclei are found in the bins near the ventricular surface (inner subset), and the remainder form a broader distribution extending from bin 7-11 (outer subset). The inner subset corresponds to cells of the PVE just as at the $0.5 \mathrm{hr}$ time point. However, unlike the nuclei, which are descending at the $0.5 \mathrm{hr}$ time point, those at $3.5 \mathrm{hr}$ have completed $\mathrm{M}$ phase and are ascending across the VZ, either progressing through $\mathrm{G} 1$ phase as $\mathrm{P}$ or exiting from the $\mathrm{VZ}$ as $\mathrm{Q}$ fraction cells. Just as at the $0.5 \mathrm{hr}$ time point, the outer subset at $3.5 \mathrm{hr}$ corresponds to the SPP.

At progressively later intervals through the $8.0 \mathrm{hr}$ time point, the distributions of labeled nuclei remain bimodal (Fig. 6). The peak of the inner subset distribution is progressively displaced away from the ventricular surface (Fig. 7). From the mean nuclear position of the inner subset (Table 1), it is estimated that the average rate of ascent of nuclei within the $\mathrm{VZ}$ is $0.58 \mathrm{bin} / \mathrm{hr}$, or $\sim 6$ $\mu \mathrm{m} / \mathrm{hr}(10 \mu \mathrm{m} / \mathrm{bin} \times(4.30-1.69 \mathrm{bin}) /(8.0-3.5 \mathrm{hr}))$. However, if one considers the full sequence of shifts in position over the 3.5 to $8.0 \mathrm{hr}$ time points, there appears to be a modest acceleration in velocity over the course of the ascent through the VZ (Fig. 7). Such a pattern of acceleration also was suggested by observations in an earlier analysis (Takahashi et al., 1993).

The position of the peak of the distribution of the outer subset is more stable with a slight upward displacement at the $8.0 \mathrm{hr}$ time point (Fig. 7). As we discuss below in Rapidly Exiting and More Slowly Exiting Subpopulations (Results section), there is a subset of $\mathrm{Q}$ fraction cells that exits the VZ (i.e., inner subset) rapidly and

Table 1. Changes in cohort position

\begin{tabular}{|c|c|c|c|c|c|c|}
\hline Time points & & $0.5 \mathrm{hr}$ & $3.5 \mathrm{hr}$ & $5.0 \mathrm{hr}$ & $6.5 \mathrm{hr}$ & $8.0 \mathrm{hr}$ \\
\hline \multirow[t]{2}{*}{$\begin{array}{l}\text { (1) Mean posi- } \\
\text { tion of the } \\
\text { cells in each } \\
\text { subset (bin) }\end{array}$} & Inner & 1.15 & 1.69 & 2.13 & 3.20 & 4.30 \\
\hline & Outer & 7.55 & 9.09 & 8.99 & 9.37 & 10.18 \\
\hline \multicolumn{7}{|l|}{$\begin{array}{l}\text { (2) Number of } \\
\text { cells/sector } \\
\text { (average }=\end{array}$} \\
\hline \multirow[t]{3}{*}{$9.54)$} & Inner & 6.75 & 6.89 & 7.26 & 8.07 & 7.16 \\
\hline & Outer & 0.94 & 0.98 & 2.15 & 2.88 & 2.75 \\
\hline & Total & 7.69 & 7.87 & 9.41 & 10.95 & 9.91 \\
\hline \multicolumn{7}{|l|}{ (3) Relative size } \\
\hline$(\%)$ & Inner & 87.8 & 87.5 & 77.2 & 73.7 & 72.3 \\
\hline & Outer & 12.2 & 12.5 & 22.8 & 26.3 & 27.7 \\
\hline & Total & 100 & 100 & 100 & 100 & 100 \\
\hline
\end{tabular}




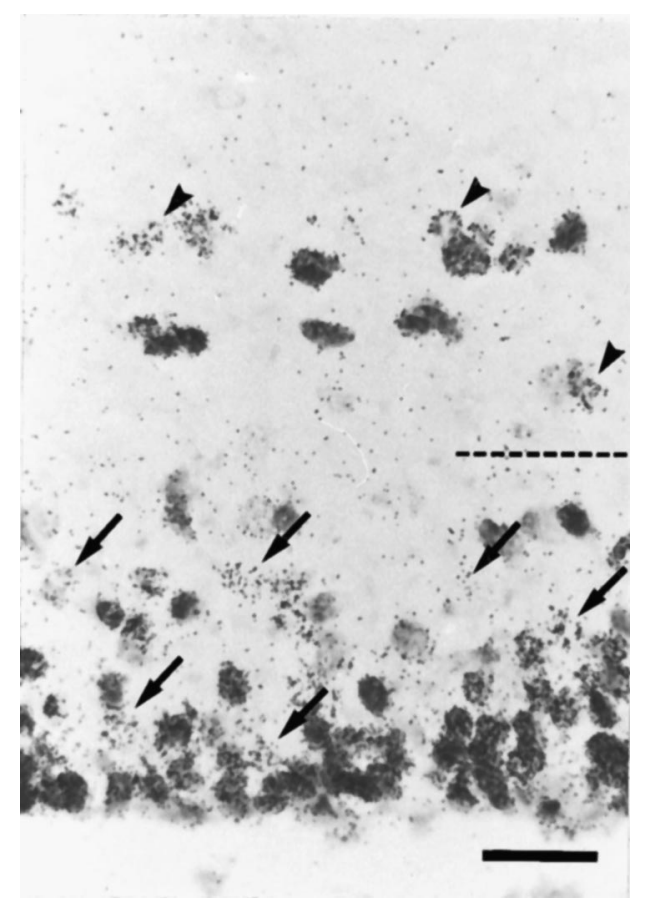

Figure 5. The $1 \mathrm{hr}$ cohort at the $6.5 \mathrm{hr}$ time point as illustrated in a photomicrograph. The boundary between VZ and SVZ is indicated by a dashed line. $\left[{ }^{3} \mathrm{H}\right] \mathrm{TdR}$-only labeled cells, representing both rapidly exiting cells of the PVE Q fraction $\left(Q_{\mathrm{r}}\right)$ and G1 phase cells of the SPP, are found in the SVZ and IZ (arrowheads). Cells of the $1 \mathrm{hr}$ cohort located within the VZ (arrows) must be either cells of the PVE in G1 phase (i.e., the P fraction of the cohort) or slowly ascending cells of the $\mathrm{Q}$ fraction of the cohort $\left(Q_{\mathrm{s}}\right)$ that have not yet exited the VZ. Scale bar, $20 \mu \mathrm{m}$.

joins the outer subset. We assume that the slight upward displacement of the outer subset during this interval reflects migration of the rapidly exiting cells.

We have estimated the descending velocity of nuclei during $\mathrm{S}$ and G2 phases as follows (see also Takahashi et al., 1993). With interkinetic nuclear migration, nuclei of the PVE undergo $S$ phase in the outer half of the VZ (S-phase zone) (Figs. 1, 4). They descend through the $S$-phase zone toward the ventricular surface. The width of the S-phase zone at E14 is $\sim 40 \mu \mathrm{m}$ and $T_{\mathrm{S}}$ at this age is $\sim 4 \mathrm{hr}$. It follows that for the average nucleus in S phase at E14, it takes $\sim 4 \mathrm{hr}$ to traverse $40 \mu \mathrm{m}$. Within only $1 \mathrm{hr}$ of entering G2 phase, the nucleus has crossed the inner 30-40 $\mu \mathrm{m}$ of the VZ to reach the ventricular surface, where it undergoes mitosis. Thus, the mean nuclear velocity is $10 \mu \mathrm{m} / \mathrm{hr}$ in $\mathrm{S}$ phase and as much as $40 \mu \mathrm{m} / \mathrm{hr}$ in $\mathrm{G} 2$ phase. In M phase, the nucleus is at a standstill, that is, its velocity is 0 (Takahashi et al., 1993).

\section{Relative sizes of the two subsets of the $1 \mathrm{hr}$ cohort}

Given that the combined length of G2 and M phases is $\sim 2 \mathrm{hr}$ (Takahashi et al., 1993, 1995a,b), all of the cells in both the inner (PVE) and outer (SPP) subsets of the $1 \mathrm{hr}$ cohort will undergo mitosis between the $0.5 \mathrm{hr}$ and $3.5 \mathrm{hr}$ time points. As expected from this consideration, the relative sizes of the inner (PVE) and outer (SPP) subsets remain unchanged at the $3.5 \mathrm{hr}$ time point (the inner subset, 87.5\%; the outer subset, 12.5\%). However, there appears to be a reciprocal change in the relative sizes of the two subsets over the 3.5-8.0 hr interval. Thus, the relative size of the outer subset increases from $12.5 \%$ at $3.5 \mathrm{hr}$ to $22.8 \%$ at $5.0 \mathrm{hr}$, $26.3 \%$ at $6.5 \mathrm{hr}$, and $27.7 \%$ by $8.0 \mathrm{hr}$ (Table 1, row 3). This suggests that cells are shifting from the inner subset within the VZ
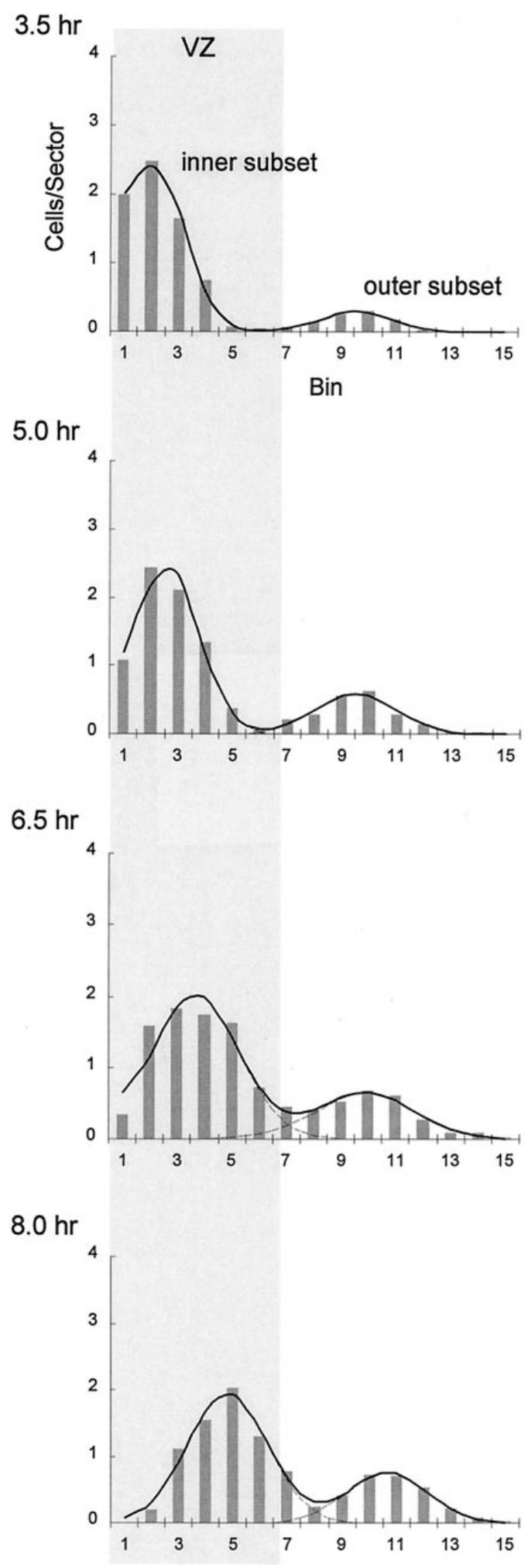

Figure 6. The $1 \mathrm{hr}$ cohort distribution in the $3.5-8.0 \mathrm{hr}$ interval mapped as histograms. $\left[{ }^{3} \mathrm{H}\right] \mathrm{TdR}$-only labeled cells are scored with respect to 10 $\mu \mathrm{m}$ bin position and plotted as histograms at the 3.5, 5.0, 6.5, and $8.0 \mathrm{hr}$ time points after exposure to BUdR. Through the first $8.0 \mathrm{hr}$, the two subsets of cells (the inner and outer subsets) remain well separated and distinct from each other. Because the distributions of the inner and outer subsets of cells are well approximated by two normally distributed populations, the mean positions and relative sizes of the two distributions can be calculated from a least-squares fit to the frequency histograms (dashed lines) (Table 1). The sum of the two distributions is shown with solid lines. 


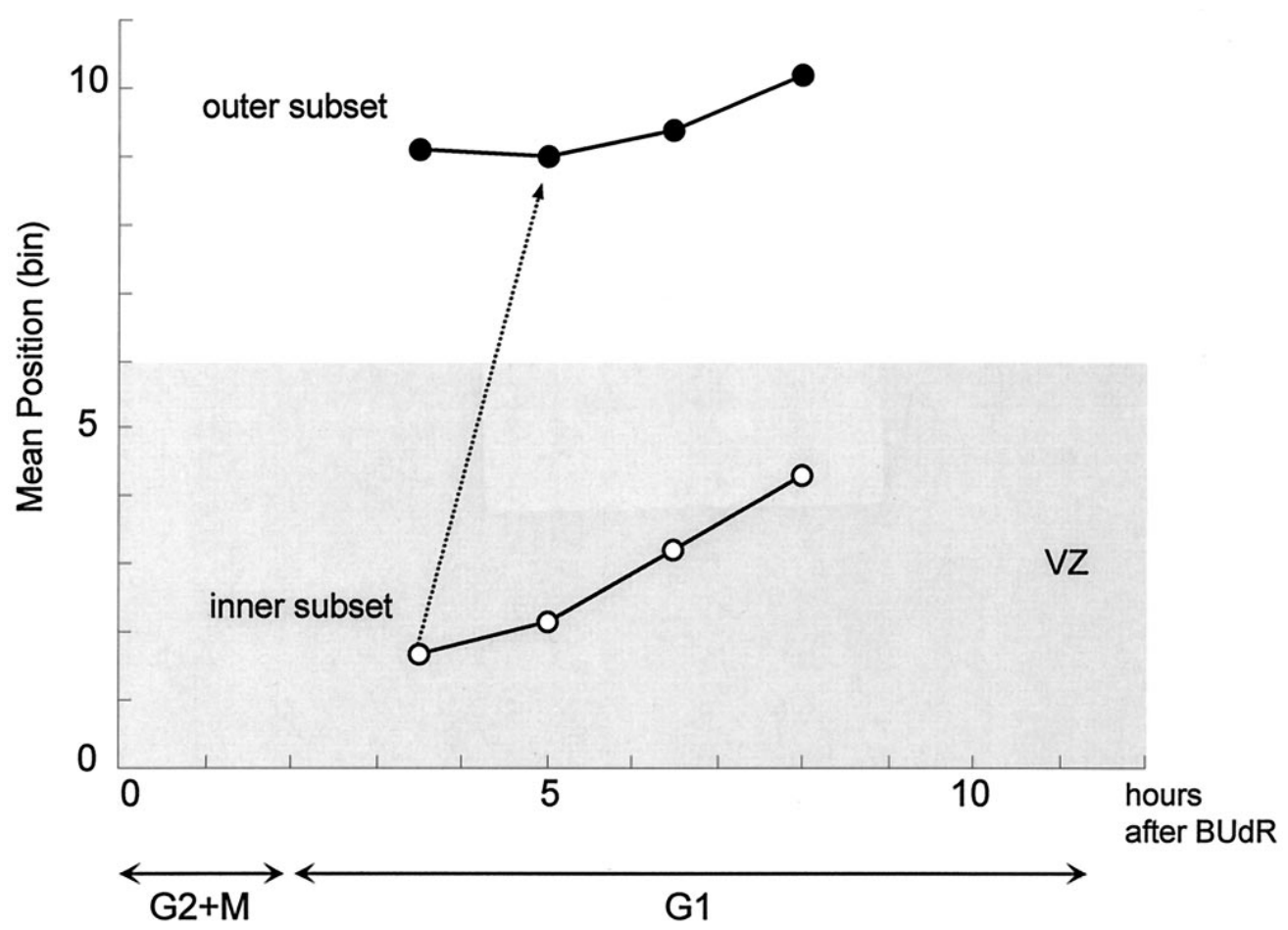

Figure 7. Changing positions of the two subpopulations of the $1 \mathrm{hr}$ cohort over the 3.5-8.0 hr interval. This interval corresponds approximately to the G1 phase of the P cells of the cohort. The locations of the inner subset within the VZ and the outer subset above the $\mathrm{VZ}$ are plotted with respect to average bin position. Approximately $15 \%$ of the cells of the cohort move from the inner subset to the outer subset as early as 5 $\mathrm{hr}$ after BUdR injection, which corresponds to $Q_{\mathrm{r}}$ of the PVE. This movement is indicated by an arrow with dashed line (for details, see Results).

(cells arising from proliferation within the PVE) to the outer subset (at $3.5 \mathrm{hr}$, the outer subset would have included cells arising within the SPP only). This means that some cells (i.e., $\sim 15 \%$ of the total) are moving out of the VZ rapidly as they exit from the PVE.

\section{Sensitivity of detection of postmitotic neurons}

We have established previously that the sensitivity of the $\left[{ }^{3} \mathrm{H}\right] \mathrm{TdR}$ method as used here for detection of G2 phase nuclei is $\sim 75 \%$ that of the BUdR-based method (Takahashi et al., 1995b). In the present experiments, the premitotic cohort size at $0.5 \mathrm{hr}$ is 7.69 cells, whereas the average postmitotic (at 3.5, 5.0, 6.5, $8.0 \mathrm{hr}$ ) cohort size is 9.54 cells (Table 1, row 2). Thus, we observe an apparent increase in the premitotic to postmitotic cohort size of only 1.24 times (9.54/7.69) rather than the expected 2.0 times; that is, the autoradiographic method as used here has an overall sensitivity of $\sim 60 \%(1.24 / 2.0)$ for the detection of change in cohort size as a result of mitosis. The overall sensitivity of the autoradiographic method as used here for detection of postmitotic $\left[{ }^{3} \mathrm{H}\right] \mathrm{TdR}$-labeled nuclei is, thus, $45 \%(=75 \% \times 60 \%)$. We are doubtful that cell death contributes substantially to this low level of sensitivity of the autoradiographic method for detecting labeled cells.

A recent study based on staining with ISEL+ estimates cell death in the VZ and across the cerebral wall through E14 to be at least $50-70 \%$ (Blaschke et al., 1996). This high rate of cell death would preclude growth of the PVE and also the acceleration in the output of neurons from the PVE over the course of the neuronogenetic interval. That both phenomena occur is incontrovertible (Rakic, 1974; Luskin and Shatz, 1985; Bayer and Altman, 1991). The invariance in the actual numbers of cells of the $2 \mathrm{hr}$ cohort observed here (Table 2) (12.5 hr time point through P4) throughout their migrations into the cortex also is inconsistent with the high estimates of cell death within the cerebral wall (Blaschke et al., 1996). Whatever the true rate of cell death, this factor would not influence our characterization of the exit and migratory behavior of cells of the $\mathrm{Q}$ fraction unless it were selective for $Q_{\mathrm{r}}$ or $Q_{\mathrm{s}}$ (to be characterized), which would seem improbable.

The relative numbers of $\mathrm{Q}$ fraction cells of the $2 \mathrm{hr}$ cohort was approximately double that of the $1 \mathrm{hr}$ cohort at $12.5 \mathrm{hr}$ (Fig. 8), indicating that the sensitivity of the autoradiographic method is the same whether applied to the $1 \mathrm{hr}$ or the $2 \mathrm{hr}$ cohort series of experiments. We assume that the drop in sensitivity after mitosis reflects a number of nonstoichiometric properties of autoradiography. For example, a change in the size of the nucleus or an unequal distribution of $\left[{ }^{3} \mathrm{H}\right] \mathrm{TdR}$ to two daughter cells may mean that fewer cells would generate an autoradiographic grain count sufficient to cross a threshold needed for recognition (Windrem and Nowakowski, 1993) (R. Nowakowski, personal communication).

\section{Cell exit from the VZ}

The average size of the $1 \mathrm{hr}$ cohort before $T_{\mathrm{c}}-T_{\mathrm{s}}$, that is, before $\mathrm{P}$ and $\mathrm{Q}$ are separable, is 9.54 whereas the size after $T_{\mathrm{c}}-T_{\mathrm{s}}$ (at $12.5 \mathrm{hr}$ ), that is, with only $\mathrm{Q}$ included, becomes reduced to 3.56 (Table 2). Thus, the $\mathrm{Q}$ fraction for the entire proliferative population (essentially that of the PVE) estimated here is 0.37 (3.56/ 9.54). This value is essentially identical to (and, hence, corroborates) a previous estimate where injection schedules (both for $\mathrm{P}+$ $\mathrm{Q}$ and for Q; the animals were sacrificed after $T_{\mathrm{c}}-T_{\mathrm{s}}$ ) and size of the cohort $(2 \mathrm{hr})$ were different from those of the present study

\begin{tabular}{lllllll}
\hline Table 2. Number of cells in the cohort & & & & \\
& $<\mathrm{Tc}-\mathrm{Ts}$ & $12.5 \mathrm{hr}$ & $12.5-60 \mathrm{hr}$ & $\mathrm{P} 4$ & $\mathrm{P} 22$ \\
\hline Original cohort size & $1 \mathrm{hr}$ & $1 \mathrm{hr}$ & $2 \mathrm{hr}$ & $2 \mathrm{hr}$ & $2 \mathrm{hr}$ \\
$\begin{array}{l}\text { Fraction included } \\
\begin{array}{c}\text { Average number of } \\
\text { cells/sector } \pm \mathrm{SEM}\end{array}\end{array}$ & $P+Q$ & $Q$ & $Q$ & $Q$ & $Q$ \\
\hline
\end{tabular}




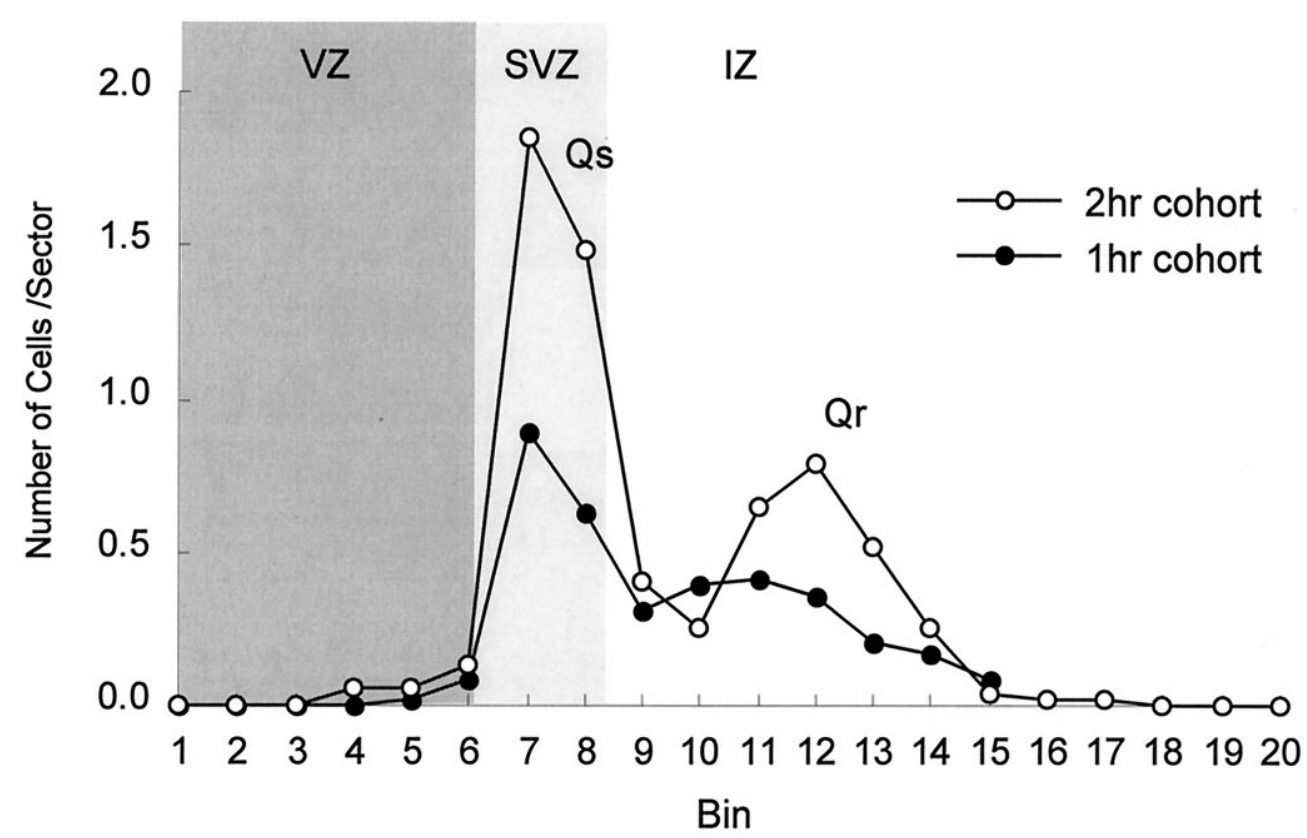

Figure 8. Comparative distributions of the 1 and $2 \mathrm{hr}$ cohorts at the $12.5 \mathrm{hr}$ time point. The distributions of cells of the 1 and $2 \mathrm{hr}$ cohorts are plotted with respect to bin position. At the $12.5 \mathrm{hr}$ time point, which is at a time $>T_{\mathrm{C}}-T_{\mathrm{S}}$, the two cohorts have been reduced to their $\mathrm{Q}$ fractions only and already have exited the VZ) The Q fractions of both cohorts are represented by two distributions corresponding to the slowly exiting $\left(Q_{s}\right)$ subpopulation, located at the VZ-SVZ border, and the rapidly exiting $\left(Q_{r}\right)$ subpopulation, located more superficially in the IZ. The number of cells in the $2 \mathrm{hr}$ cohort is approximately twice the number in the $1 \mathrm{hr}$ cohort (Table 2). Reflecting the $1 \mathrm{hr}$ longer interval between $\left[{ }^{3} \mathrm{H}\right] \mathrm{TdR}$ and BUdR injections, the $Q_{\mathrm{s}}$ and $Q_{\mathrm{r}}$ distributions of the $2 \mathrm{hr}$ cohort have shifted slightly outward with respect to those of the $1 \mathrm{hr}$ cohort.
(Takahashi et al., 1994) (unpublished observations). A Q fraction of 0.37 means that after a survival time of $12.5 \mathrm{hr}, 63 \%$ of the total PVE contingent of the cohort, corresponding to the $\mathrm{P}$ fraction, re-enters $\mathrm{S}$ phase.

\section{Rapidly exiting and more slowly exiting subpopulations}

Because the cells of the $\mathrm{Q}$ fraction make up $\sim 37 \%$ of the total cells in the cohort and $\sim 15 \%$ of the total cohort exits the PVE rapidly (as described above), the cells of the $\mathrm{Q}$ fraction must exit the PVE as two discrete subpopulations (Fig. 8) (Takahashi et al., 1994). At the $12.5 \mathrm{hr}$ time point, one subpopulation, designated $Q_{\mathrm{r}}$ ( $\mathrm{r}$ for rapidly exiting), is in the IZ. The second subpopulation, designated $Q_{\mathrm{s}}$ (s for slowly exiting), is at the VZ-SVZ border. It is to be noted that the two subpopulations, $Q_{\mathrm{r}}$ and $Q_{\mathrm{s}}$, do not correspond to the SPP and PVE subpopulation partitions of the 1 hr cohort observed premitotically at the $0.5 \mathrm{hr}$ time point. Both the $Q_{\mathrm{r}}$ and $Q_{\mathrm{s}}$ subpopulations consist of cells of the $\mathrm{Q}$ fraction from both PVE and SPP components of the original premitotic cohorts. However, it is determined from the relative sizes of their respective contributions to the cohort (88\% from PVE, $12 \%$ from SPP) and the values of their Q fractions ( 0.37 for PVE, 0.1 for SPP) (Takahashi et al., 1994, 1995b) (unpublished observations) that the number of cells in the SPP contingent of the total $\mathrm{Q}$ fraction population of the cohort is only $4 \%$ (i.e., $0.12 \times 0.1$ / $\{(0.88 \times 0.37)+(0.12 \times 0.1)\}=4 \%)$. Therefore, the PVE contingent at $96 \%$ is by far the dominant subpopulation of the $\mathrm{Q}$ fraction. Because the SPP contingent is such a minor contributor to the $\mathrm{Q}$ fraction population, we will ignore the SPP component in our analysis of neuronal migratory movements to be based on tracking the $Q_{\mathrm{r}}$ and $Q_{\mathrm{s}}$ subpopulations.

At $12.5 \mathrm{hr}$, the $Q_{\mathrm{r}}$ and $Q_{\mathrm{s}}$ subpopulations of the $2 \mathrm{hr}$ cohort have configurations that are closely similar to those of the $Q_{\mathrm{r}}$ and $Q_{\mathrm{s}}$ subpopulations of the $1 \mathrm{hr}$ cohort (Fig. 8). However, both $Q_{\mathrm{r}}$ and $Q_{\mathrm{s}}$ of the $2 \mathrm{hr}$ cohort are displaced slightly outward relative to the corresponding subpopulations of the $1 \mathrm{hr}$ cohort (Fig. 8). This displacement corresponds, we assume, to the greater distance migrated by cells of the $2 \mathrm{hr}$ cohort during the $1 \mathrm{hr}$ difference in the survival times (note, in particular, that the $2 \mathrm{hr}$ cohort contains all of the cells of the $1 \mathrm{hr}$ cohort plus cells that left the $\mathrm{S}$ phase in the preceding additional hour) (see the legend for Fig. 2). At 12.5 hr, $Q_{\mathrm{s}}$ of the $2 \mathrm{hr}$ cohort, $\sim 60 \%$ of the entire $\mathrm{Q}$ fraction, lies at the VZ-SVZ border (average position, bin 6.9), whereas $Q_{\mathrm{r}}$ is centered more superficially in the cerebral wall at bin 11.3, a position that is well within the IZ (Fig. 8, Table 3). No stragglers appear to be left within the VZ among the $\mathrm{Q}$ fraction of the cohort; that is, no $\left[{ }^{3} \mathrm{H}\right] \mathrm{TdR}$-only labeled cells remain sequestered within the VZ beyond the time that the $\mathrm{P}$ fraction re-enters $\mathrm{S}$ phase. This observation is consistent with cell cycle kinetic analyses that indicate that the growth fraction of the PVE is 1.0 (Waechter and Jaensch, 1972; Takahashi et al., 1993, 1995a). The observation that essentially all $\mathrm{Q}$ fraction cells of the cohort have exited the $\mathrm{VZ}$ within an interval corresponding to $T_{\mathrm{C}}-T_{\mathrm{S}}$ also is consistent with the finding that there is relatively little variation in $T_{\mathrm{C}}$ among cells of the PVE cycling at any given moment (Waechter and Jaensch, 1972; Cai et al., 1993; Takahashi et al., 1993, 1995a).

Thus, two lines of evidence, based on these observations, suggest that the overall Q fraction at E14 includes rapidly exiting and more slowly exiting subpopulations. The first line of evidence is a reciprocal change in the relative sizes of the two distributions (i.e., the inner subset within the VZ and the outer subset above the VZ, illustrated in Fig. 6 and referred to as inner and outer subsets, respectively) over the $3.5-8.0 \mathrm{hr}$ interval. Increase in size of the outer subset signals the first appearance of a portion of the PVE $\mathrm{Q}$ fraction cells in the zone external to the VZ. The second line of evidence is that at $12.5 \mathrm{hr}$, the $\mathrm{Q}$ fraction has segregated into two spatially separate subpopulations. (We have designated these as $Q_{\mathrm{r}}$ and $Q_{\mathrm{s}}$ for rapidly exiting and slowly exiting subpopulations of $\mathrm{Q}$, respectively) (Fig. 8). In addition, it should be noted that it was

Table 3. Mean position of the cells in each of the distributions (bin)

\begin{tabular}{lccccc} 
& $12.5 \mathrm{hr}$ & $24 \mathrm{hr}$ & $36 \mathrm{hr}$ & $48 \mathrm{hr}$ & $60 \mathrm{hr}$ \\
\hline$Q_{\mathrm{r}}$ & 11.3 & 13.6 & 21.2 & 23.1 & 30.8 \\
$Q_{\mathrm{s}}$ & 6.9 & 9.3 & 17.0 & 23.1 & 30.8 \\
$\begin{array}{l}\text { Interpeak } \\
\text { distance }\end{array}$ & 4.4 & 4.3 & 4.2 & NA & NA \\
\hline
\end{tabular}

NA indicates not applicable. 


\begin{tabular}{|c|c|c|c|c|}
\hline Hours after $\mathrm{S}$ phase & $12.5-24 \mathrm{hr}$ & $24-36 \mathrm{hr}$ & $36-48 \mathrm{hr}$ & $48-60 \mathrm{hr}$ \\
\hline \multicolumn{5}{|l|}{ (1) Distance traveled } \\
\hline$Q_{\mathrm{r}}$ & 2.3 & 7.6 & 1.9 & 7.7 \\
\hline$Q_{\mathrm{s}}$ & 2.4 & 7.7 & 6.1 & 7.7 \\
\hline $\begin{array}{l}\text { (2) Migration rate } \\
(\mu \mathrm{m} / \mathrm{hr})\end{array}$ & 2.0 & 6.4 & $\begin{array}{l}1.6\left(Q_{\mathrm{r}}\right) \\
5.1\left(Q_{\mathrm{s}}\right)\end{array}$ & 6.4 \\
\hline
\end{tabular}

observed in a previous analysis based on cumulative BUdR labeling that there are two groups of PVE Q fraction cells, one sluggish and the other rapid in terms of exit from the VZ (Takahashi et al., 1993).

Some of the PVE $\mathrm{Q}$ fraction cells (i.e., $Q_{\mathrm{r}}$ ) of the cohort accumulate above the $\mathrm{VZ}$ as early as $5 \mathrm{hr}$ after exit from $\mathrm{S}$ phase or $3 \mathrm{hr}$ after mitosis (i.e., at the $5.0 \mathrm{hr}$ time point), that is, well before their sister cells of the $\mathrm{P}$ fraction complete $\mathrm{G} 1$ phase (length of G1 phase on E14 = 9.3 hr). The mean position of the inner subset at the $3.5 \mathrm{hr}$ time point is 1.69 bins and that of the outer subset at $5.0 \mathrm{hr}$ is at bin 8.99 (Table 1, row 1). Thus, cells comprising $Q_{\mathrm{r}}$ will have traveled 7.3 bins $(8.99-1.69)$ or $73 \mu \mathrm{m}$ in $1.5 \mathrm{hr}(5.0 \mathrm{hr}-3.5 \mathrm{hr})$ corresponding to an exit velocity of $\sim 50$ $\mu \mathrm{m} / \mathrm{hr}$ (indicated by an arrow with dashed line in Fig. 7). This estimate is $\sim 1.5$ times that of the fastest exit behaviors in the ferret measured in slice preparations by high-precision techniques (O’Rourke et al., 1992; Chenn and McConnell, 1993, 1995). This difference is of uncertain significance, however, because our estimate may be somewhat imprecise because of the compounded difficulties of estimating the short distances migrated during exit from the VZ and by the relative imprecision of our pattern of temporal sampling. There also could be mouse/ferret species differences.

$Q_{\text {s }}$ is distributed at the VZ-SVZ border (mean position, 6.9) (Table 3 ) at the $12.5 \mathrm{hr}$ point. Thus, exit velocity of the $Q_{\mathrm{s}}$ cells is 6.9 (at $12.5 \mathrm{hr}$ ) -1.69 (at $3.5 \mathrm{hr}$ ) $/ 12.5-3.5 \mathrm{hr}=0.58$ bins or $\sim 6$ $\mu \mathrm{m} / \mathrm{hr}$, which is only approximately one-eighth the apparent velocity of the $Q_{\mathrm{r}}$ cells. Because the $\mathrm{P}$ fraction cells re-enter $\mathrm{S}$ phase at $T_{\mathrm{c}}-T_{\mathrm{s}}$ near the upper margin of the VZ (Takahashi et al., 1992), the rate of ascent of nuclei of cells in G1 phase should be essentially the same as that of $Q_{\mathrm{s}}$.

\section{Cell migration across the cerebral wall}

During the subsequent $12.5-36 \mathrm{hr}$ interval, $Q_{\mathrm{r}}$ and $Q_{\mathrm{s}}$ ascend across the IZ to reach the developing cortex (histograms in Fig. 9, photomicrographs in Fig. $10 \mathrm{~A}$ ). Beyond $12.5 \mathrm{hr}$, these two subpopulations remain stable and separate with no significant change in the $40 \mu \mathrm{m}$ spatial interval in the course of their migration across the IZ (Table 3). This indicates that the neurons in $Q_{\mathrm{s}}$ and $Q_{\mathrm{r}}$ migrating at any given moment across the IZ do so at approximately the same velocities. Thus, the subpopulations of the $\mathrm{Q}$ fraction that appear to differ as much as eight times with respect to their exit velocities from the VZ $(6 \mu \mathrm{m} / \mathrm{hr}$ compared with 50 $\mu \mathrm{m} / \mathrm{hr}$ ) appear not to differ with respect to their migration velocities.

The distance traveled by $Q_{\mathrm{r}}$ and $Q_{\mathrm{s}}$ in the $12.5-24 \mathrm{hr}$ interval is $\sim 24 \mu \mathrm{m}(2.3,2.4 \mathrm{bins})$ and in the $24-36 \mathrm{hr}$ interval $\sim 77 \mu \mathrm{m}(7.6$, 7.7 bins) (Table 4, row 1), corresponding to migratory rates of $\sim 2.0$ and $6.4 \mu \mathrm{m} / \mathrm{hr}$ for these two intervals (Table 4, row 2). These average rates of migration are in the general range of 4.5-20 $\mu \mathrm{m} / \mathrm{hr}$ for neocortical and cerebellar neurons estimated elsewhere in vivo and in vitro in mouse and monkey (Nowakowski and Rakic,
1979; Edmondson and Hatten, 1987; Gadisseux et al., 1990; Fishell and Hatten, 1991; Komuro and Rakic, 1993; Rakic et al., 1994). We have ignored the increase in the length of the migratory route (i.e., the width of the IZ) in our estimates of migration rates for $Q_{\mathrm{r}}$ and $Q_{\mathrm{s}}$ for the following reasons: (1) the length of the entire SVZ-IZ migratory route will change only by $20 \mu \mathrm{m}$, or $25 \%$, during the period that migration of $Q_{\mathrm{r}}$ and $Q_{\mathrm{s}}$ occurs; (2) it is uncertain whether the $25 \%$ increase in the SVZ-IZ migratory route modifies the IZ thickness uniformly (i.e., equally at the various levels of the IZ) or nonuniformly (i.e., differently at different levels of the IZ); (3) the long temporal gaps between samplings during the migratory period for the cohort (i.e., $12 \mathrm{hr}$ between experiments) does not allow a finer-grained tracking of the migratory rates of these cells.

As the cells of $Q_{\mathrm{r}}$ enter the developing cortex during the 36-48 $\mathrm{hr}$ interval, there is a decrease in migration rate $(6.4$ to $1.6 \mu \mathrm{m} / \mathrm{hr})$ (Table 4, row 2, Fig. 11). Within the cortex, $Q_{\mathrm{r}}$ and $Q_{\mathrm{s}}$ form a single modal distribution within which $Q_{\mathrm{r}}$ and $Q_{\mathrm{s}}$ no longer are distinguishable as separate distributions (Figs. 9, 10B). From the distance traveled by the "merged" $Q_{\mathrm{r}}$ and $Q_{\mathrm{s}}$, it is calculated that the migration rate is resumed at $\sim 6.4 \mu \mathrm{m} / \mathrm{hr}$ as the cohort ascends through the developing cortex (Table 4, row 2).

\section{Postmigratory cell redistribution within the cortex}

At both $\mathrm{P} 4$ and $\mathrm{P} 22$, the density of the $\mathrm{Q}$ fraction cells is maximum over cortical layer V (Figs. 10C, 12). The profile of the distribution, as it extends above and below layer $\mathrm{V}$, is approximately symmetric at both ages. At P4, the nuclei of the Q fraction cells arising on early E14 are found at all levels of the developing cortex. At P22, however, the distribution of the $\mathrm{Q}$ fraction of the cohort essentially is confined to layers VI and V and is densest in lower layer V (Fig. 12). Between P4 and P22, the mean increase in distance from the center of the cohort distribution over layer $\mathrm{V}$ to the ML above is $\sim 200 \mu \mathrm{m}$, whereas the mean increase in the distance to the external sagittal stratum below is negligible.

Although the general configuration of the intracortical distribution of the $\mathrm{Q}$ fraction is similar at $\mathrm{P} 4$ and $\mathrm{P} 22$, there is a substantial decrease in the total number of cohort cells in this interval (Table 2). Within the intracortical portion of the standard sector (now defined as subtending $400 \mu \mathrm{m}^{2}$ of cortical surface), the number of $\mathrm{Q}$ fraction cells of the cohort declines from 6.31 at $\mathrm{P} 4$ to 3.56 at $\mathrm{P} 22$, corresponding to a $45 \%$ reduction in density of cohort cells within the total intracortical sector. The decrease in the total number of cohort cells between the migration interval $(12.5-60 \mathrm{hr}, 6.92 \pm 0.23)$ (Table 2) and P4 (6.31) is only $10 \%$. The volume expansion in layer $\mathrm{V}$ of the dorsomedial (SI) region of the mouse between P5 and P20 has been estimated previously to be 1.5 times (Leuba et al., 1977; Heumann et al., 1978; Crandall and Caviness, 1984) where the expansion occurs principally in the tangential dimension. If we accept this level of tissue expansion to apply for the P4-P22 interval, the residual reduction in cell density between $\mathrm{P} 4$ and $\mathrm{P} 22$ not attributable to growth is $\sim 15 \%$. This is calculated as follows: $\{6.31$ (initial density at P4) $-3.56 \times$ 1.5 (density at P22 corrected for tissue expansion)\}/6.31 (initial density at $\mathrm{P} 4)=0.15$, or $15 \%$.

\section{DISCUSSION}

Rapidly exiting and more slowly exiting subpopulations A principal finding of the present analysis is that the $\mathrm{Q}$ fraction cells exit the PVE as two subpopulations, one rapidly exiting $\left(Q_{\mathrm{r}}\right)$ and the other slowly exiting $\left(Q_{\mathrm{s}}\right)$. These two different exiting behaviors that we have documented for the PVE Q fraction may 


\section{$12.5 \mathrm{hr}$}

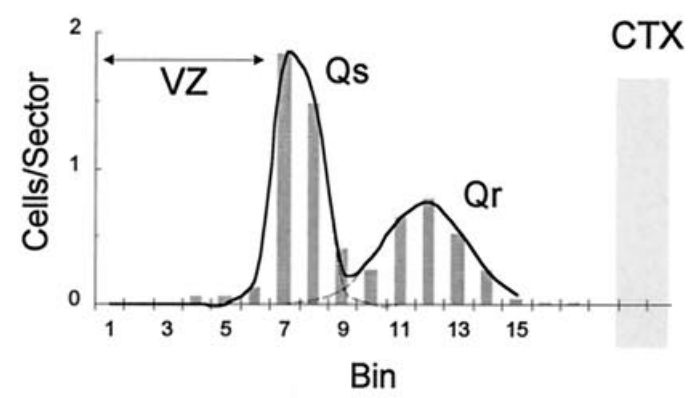

$24 \mathrm{hr}(\mathrm{E} 15,9: 00 \mathrm{am})$

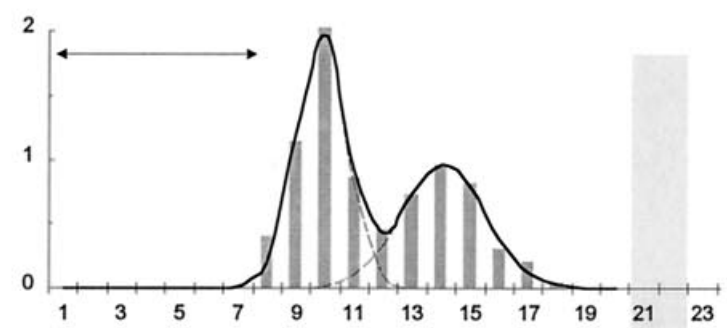

$36 \mathrm{hr}$

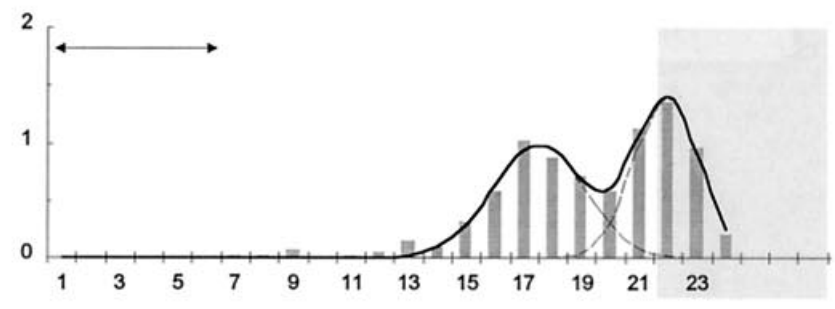

$48 \mathrm{hr}(\mathrm{E} 16,9: 00 \mathrm{am})$

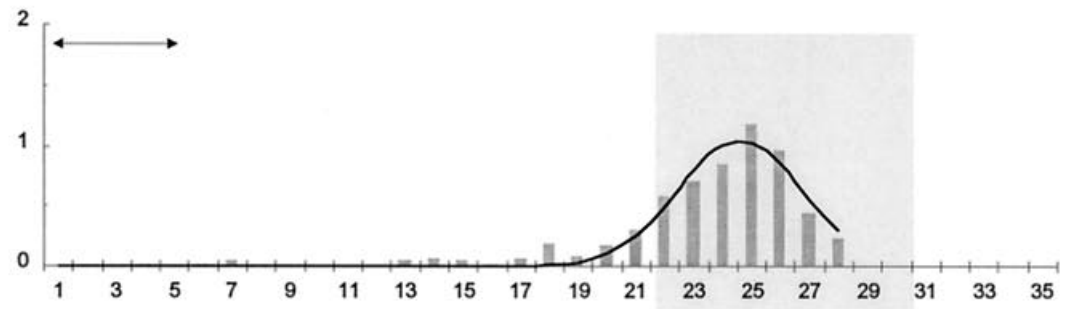

$60 \mathrm{hr}$

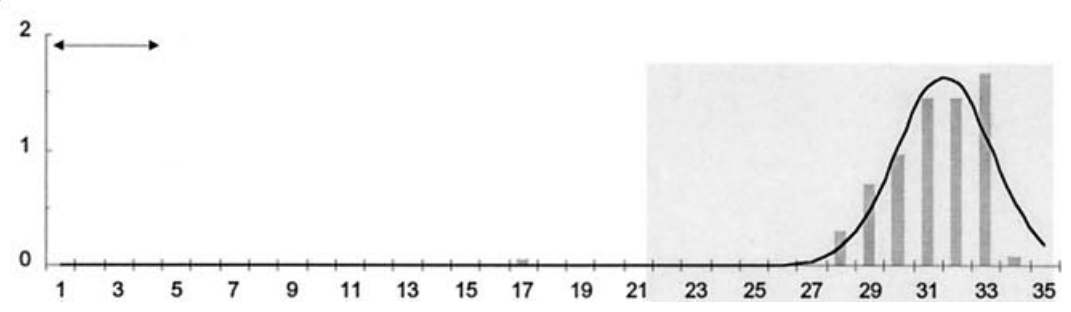

Figure 9. The $2 \mathrm{hr}$ cohort distributions in the 12.5-60 hr interval mapped as histograms. $\left[{ }^{3} \mathrm{H}\right] \mathrm{TdR}$-only labeled cells are scored with respect to $10 \mu \mathrm{m}$ bin position and plotted as histograms at the $12.5,24,36,48$, and $60 \mathrm{hr}$ time points after exposure to BUdR. The $Q_{\mathrm{r}}$ (rapidly exiting) and $Q_{\mathrm{s}}$ (slowly exiting) subpopulations of the cohort are well separated through the $36 \mathrm{hr}$ time point, that is, until the $Q_{\mathrm{r}}$ subpopulation begins to enter the cortex. At the 48 and $60 \mathrm{hr}$ time points, after both $Q_{\mathrm{r}}$ and $Q_{\mathrm{s}}$ have entered the cortex, the two populations are completely overlapping. If for the 12.5-36 hr time points, we assume that the $Q_{\mathrm{r}}$ and $Q_{\text {s }}$ subsets of cells approximate two normally distributed populations, the mean positions and relative sizes of the two distributions can be calculated from a least-squares fit to the frequency histograms (dashed lines) (Table 3). The trace shown with a solid line at each time point is a best fit to the total population of the $2 \mathrm{hr}$ cohort. correspond to the two different exit behaviors of postmitotic cells, which have been observed in slice preparations in ferret (Chenn and McConnell, 1993, 1995). After mitoses where the line of separation of daughter cells is parallel to the ventricular surface, the daughter cell arising from the abventricular pole moved quickly out of the VZ, leaving the other daughter cell at the ventricular margin. It is possible that these cells (or, perhaps, some of them) correspond to our $Q_{\mathrm{r}}$. For other mitoses where the line of separation of daughter cells is orthogonal to the ventricular surface, both daughter cells moved together more slowly away 


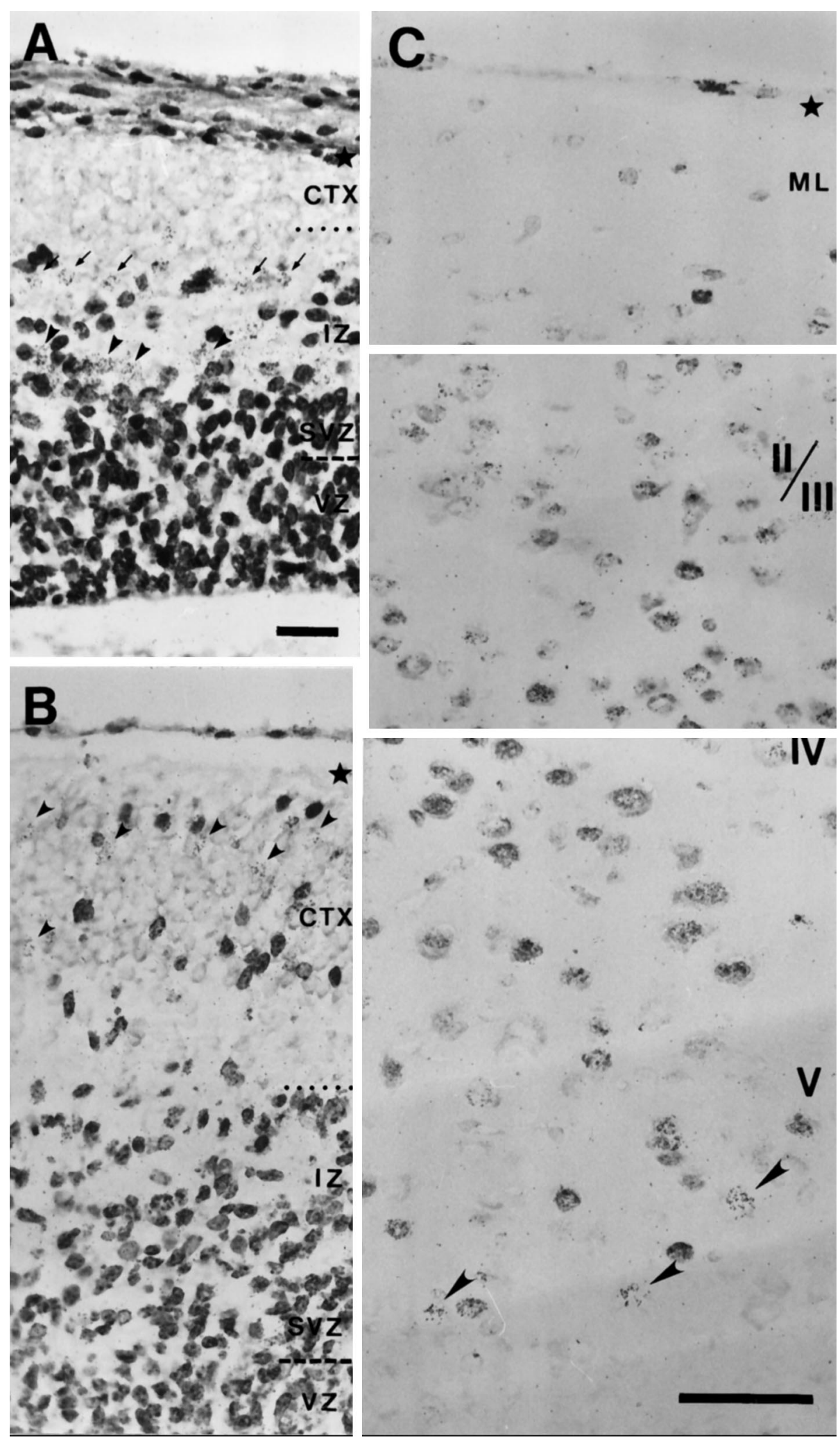

Figure 10. The $2 \mathrm{hr}$ cohort at $24 \mathrm{hr}(A)$ and 60 hr $(B)$ and at P22 $(C)$ as illustrated in photomicrographs. $\left[{ }^{3} \mathrm{H}\right] \mathrm{TdR}$-only labeled cells representing both rapidly $\left(Q_{\mathrm{r}}\right)$ (arrows in $A$ ) and slowly $\left(Q_{\mathrm{s}}\right)$ (arrowheads in $A$ ) exiting cells of the PVE Q fraction are distinctly separated from each other in the IZ at $24 \mathrm{hr}$, but are not distinguishable as two separate distributions within the cortex $(C T X)$ at $60 \mathrm{hr}$ and $\mathrm{P} 22$ (arrowheads in $B, C$ ). The ML and layers II-V are indicated for P22 $(C)$. (An atypically large number of $\left[{ }^{3} \mathrm{H}\right] \mathrm{TdR}$-only labeled cells is evident in the section selected for illustration at P22.) Scale bars: $A$ (equivalent also for $B), 30 \mu \mathrm{m} ; C, 50 \mu \mathrm{m}$. A star marks the pia.

from the ventricular margin. Some of these cells may correspond to our $Q_{\mathrm{s}}$ and others to the $\mathrm{P}$ fraction.

To be considered is the possibility that the "postmitotic sorting" observed in mouse and ferret reflects an early manifestation of fundamental distinctions between neuronal class, specifically a distinction between projection and interneuron classes. Certainly, the time that such sorting occurs is not too early for class distinctions to influence neuronal behavior. Several lines of evidence indicate that at least certain neurons are "aware" of their class destinies from at least as early as their terminal mitosis. Thus, pyramidal cells destined for layer $\mathrm{V}$ appear to be informed of their laminar destinations from as early as their final round of DNA 


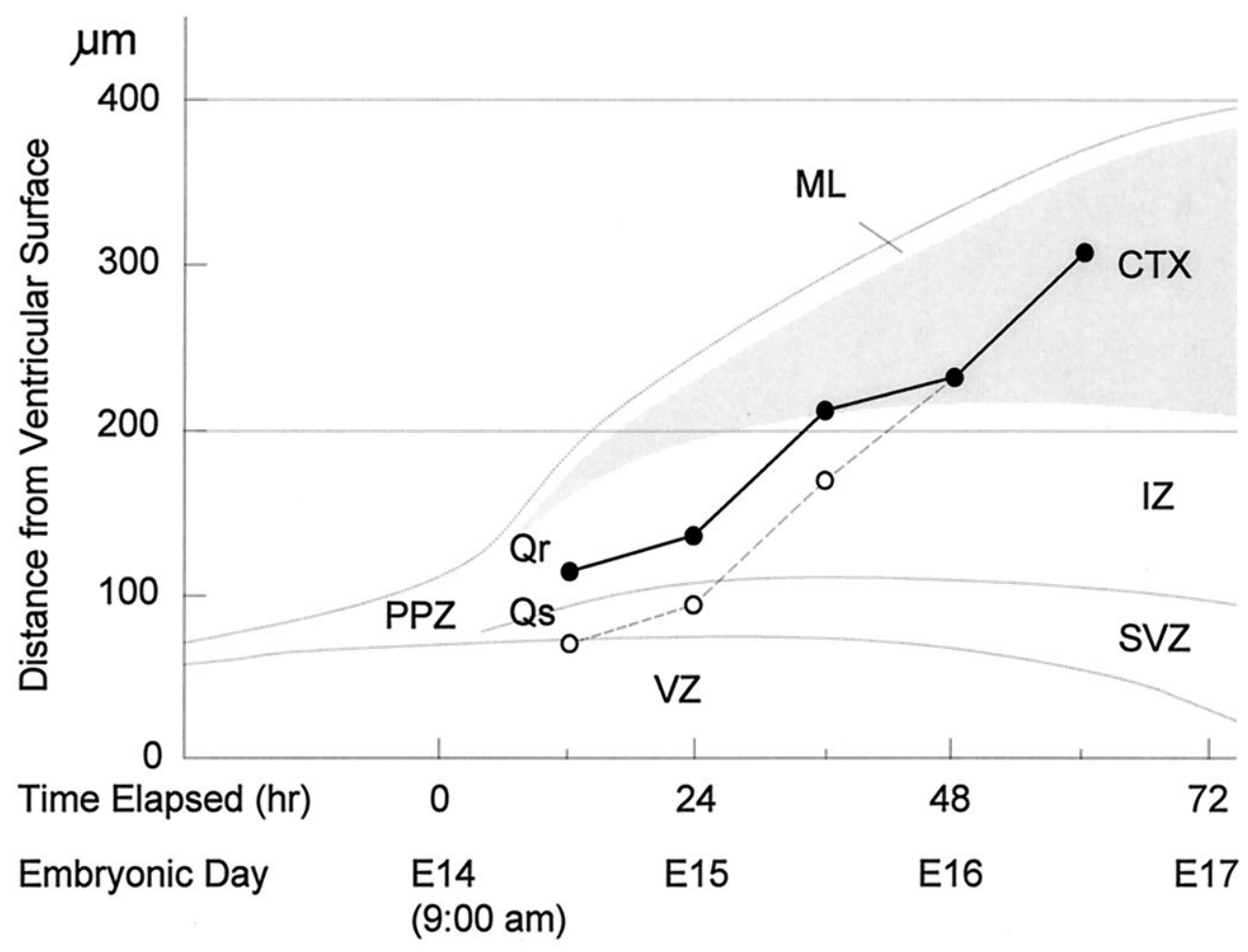

Figure 11. Comparative patterns of migration of $Q_{\mathrm{r}}$ and $Q_{\mathrm{s}}$ of the $2 \mathrm{hr}$ cohort. The mean positions of cells of the rapidly exiting $\left(Q_{r}\right.$, closed circles $)$ and slowly exiting $\left(Q_{r}\right.$, open circles) subpopulations of the $2 \mathrm{hr}$ cohort are plotted after they have left the VZ with respect to micrometers from the ventricular surface at the $12.5-60 \mathrm{hr}$ time points. Also superimposed is the stratification pattern of the cerebral wall (taken from Fig. 3). Migrations are initiated deep in the SVZ-IZ border at $12.5 \mathrm{hr}$, at which time $Q_{\mathrm{r}}$ and $Q_{\mathrm{s}}$ are well separated from each other. There is no significant change in the distance between the two subpopulations in the course of migrations through the $36 \mathrm{hr}$ time point when $Q_{\mathrm{r}}$ enters the cortex $(C T X)$. At 48 and $60 \mathrm{hr}$, after both $Q_{\mathrm{r}}$ and $Q_{\mathrm{s}}$ have entered the cortex, the two subpopulations are indistinguishable. The time elapsed after exit of the cohort from $\mathrm{S}$ phase is indicated in hours and in embryonic dates on the abscissa. synthesis (McConnell and Kaznowski, 1991). In the primate, it has been demonstrated that a subset of pyramidal neurons that contributes to the corpus callosum deploys axons to the contralateral hemisphere before the end of migration (Schwartz and Meinecke, 1992). Further, lineage tracing studies based on the $\beta$-galactosidase gene suggest that the majority of pyramidal and nonpyramidal neurons arise from separate lineages (Parnavelas et al., 1991; Mione et al., 1994). It also is clear that less commonly, both pyramidal and nonpyramidal neuronal classes may arise from a common lineage. In rodents, one or the other class appears to be eliminated by cell death during the first postnatal month (Lavdas et al., 1996). It also has been demonstrated in the developing cerebrum in primate (Schwartz and Meinecke, 1992), although without confirmation in rodents (Miller, 1986; Van Eden et al., 1989; Del Rio et al., 1992), that migrating cells express GABA even in the course of their migrations. Admittedly, because both pyramidal and nonpyramidal neurons may express both GABA and glutamate as late as the first 3 postnatal weeks (Lavdas et al., 1996), the presence of GABA in migrating neurons may not reliably identify them as representative of the nonpyramidal class.

\section{Migratory behavior of the young neurons}

The $Q_{\mathrm{r}}$ and $Q_{\mathrm{s}}$ reach the cortex sequentially with a "gap" of several hours between the arrival of the two subpopulations at the bottom of the cortex. The uniform rates of migration of the two subpopulations of the cohort may be one of several mechanisms that ensure that the final intracortical arrangement of neurons approximates the sequence in which neurons exit the PVE and initiate migration. The pattern of neuronal migration observed here is a continuous behavior. The advance of migration across the IZ is not interrupted by $24 \mathrm{hr}$ periods of arrested movement (in "sojourn zones") (Bayer and Altman, 1991) as has been postulated to be the case in rat embryos (Bayer and Altman,
1991). Every time point beyond $T_{\mathrm{C}}-T_{\mathrm{S}}(12.5-60 \mathrm{hr}$ ) (Fig. 9) sees "every cell" of $Q_{\mathrm{r}}$ and $Q_{\mathrm{s}}$ farther along its migratory path. Saltatory stop-and-go and acceleration-deceleration patterns of neuronal migration have been documented in dissociated mouse cerebellar granule cells and ferret neocortical neurons in slice preparations (Edmondson and Hatten, 1987; Fishell and Hatten, 1991; O'Rourke et al., 1992; Chenn and McConnell, 1993). These variations in movement rates occur over minutes or seconds and would not be detected with the method used here.

The increase in migratory rate with ascent across the IZ might reflect increasing differentiation of cellular mechanisms that contribute to migration competence (Rakic et al., 1974; Schwartz and Meinecke, 1992). The transient drop in migration rate on entry into the cortex might result from a "migration-slowing" change in the relation of migrating cell to the glial fiber system. In this context, it is interesting to note that migrating cells, on entering the cortex, appear to insert themselves into the glial fiber fascicles leading to a progressive defasciculation of the fibers (Gadisseux et al., 1990, 1995). We speculate that this maneuver might slow the migratory rate of the cell transiently.

\section{Cell redistribution and cell death within the cortex}

The cells of both $Q_{\mathrm{r}}$ and $Q_{\mathrm{s}}$ merge to form a single distribution within the cortex that is centered over layer $\mathrm{V}$ but which spans all cortical levels at P4 (Fig. 12). At P22, the single distribution extends from layer VI-V and is most concentrated in lower layer $\mathrm{V}$. We interpret the shift in the distribution relative to that of cortical layers as indicative of differences in patterns of dendritic growth and differentiation occurring among neurons with different times of origin. Although not directly observable by our methods, we infer that the apical dendrites of the layer $\mathrm{V}$ pyramidal cells of our cohort must have elongated as much as $450 \mu \mathrm{m}$ in the course of this displacement of the cohort from the ML after P4 (distance between the ML and the peak position of the 


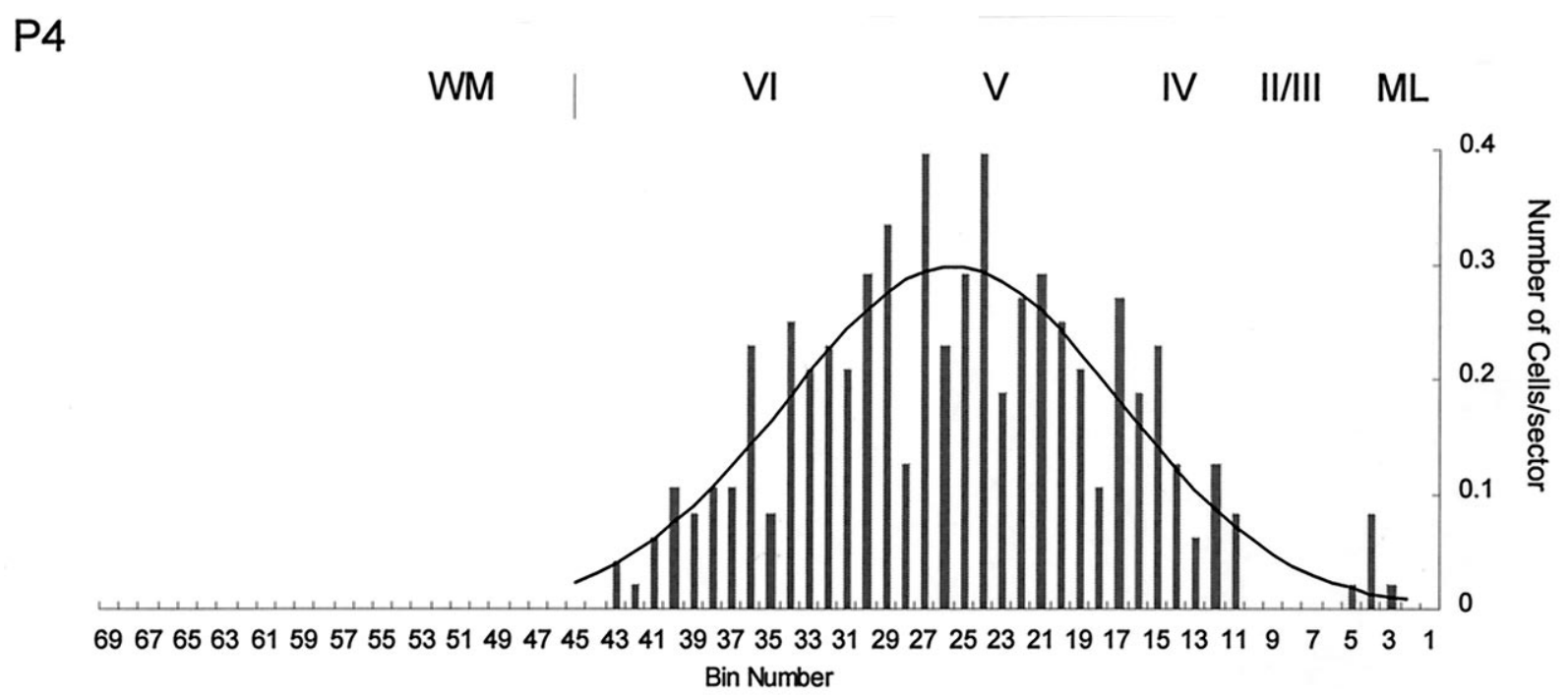

P22

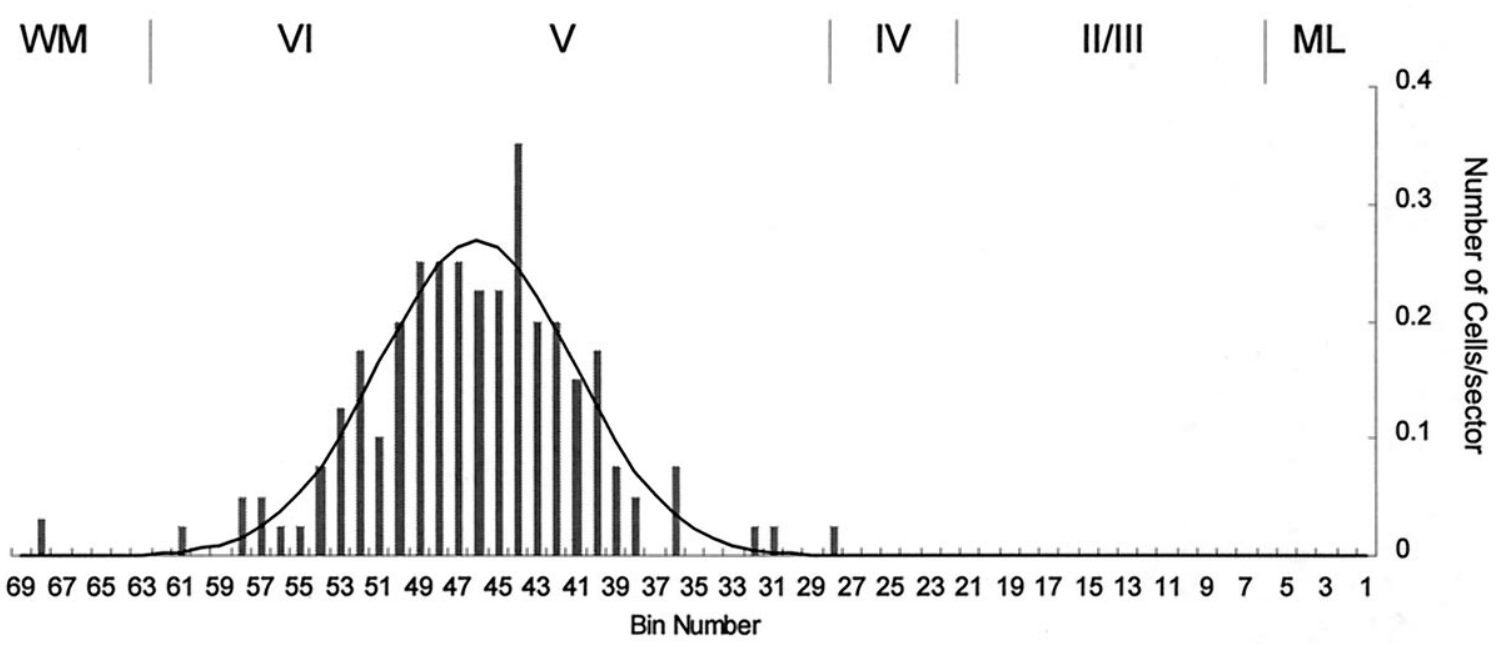

Figure 12. Comparative distributions of the $2 \mathrm{hr}$ cohort within the cortex at $\mathrm{P} 4$ and $\mathrm{P} 22 .\left[{ }^{3} \mathrm{H}\right] \mathrm{TdR}$-only labeled cells are scored with respect to $10 \mu \mathrm{m}$ bin position (referenced to the pial surface) and plotted as histograms at P4 and P22. The trace shown with a solid line at the two ages is a best fit to the total population of the $2 \mathrm{hr}$ cohort. At P4, the cohort distribution spans the full width of the cortex below the ML with the peak of the distribution located over layer V. At P22, the distribution extends only through layers VI and V, with cells most concentrated in layer V. The size of the cohort has become reduced by $45 \%$ in this 3 week interval (see Results). WM indicates cerebral white matter.

distribution at P22). Whereas the nuclei of the cohort have been shifted in position with respect to nuclei of neurons arising in preceding and succeeding cell cycles, the nuclei of cells of the cohort remain closely grouped over the first 3 postnatal weeks. (Fig. 12). This phenomenon suggests a rigorous homogeneity in the events of cell growth and differentiation among cells that undergo their terminal divisions within $2 \mathrm{hr}$ of each other.

There is no systematic variation in the size of the cohort from the early postmitotic period through the course of migrations (12.5 through $60 \mathrm{hr}$ time point). Between the migration interval (12.5-60 hr) and $\mathrm{P} 4$, there again is no significant change in the size of the cohort (only a $10 \%$ variation). In the P4-P22 interval, however, the number of cells in the $2 \mathrm{hr}$ cohort becomes reduced by almost $45 \%$ (Table 2). In principle, either tissue growth or cell death, or both processes together, might contribute to this reduction in cell density. We have estimated that $30 \%$ of the reduction in cell density observed between P4 and P22 is attributable to growth and $15 \%$ to cell death.

Therefore, the Q fraction of the cohort of cells arising on early E14 is estimated to be reduced by $\sim 15 \%$ by postnatal histogenetic cell death. This process is detected only after $\mathrm{P} 4$, that is, after cells from succeeding cell cycles have completed their migrations. It is of interest that there may be no elimination of the pyramidal neurons of layer $\mathrm{V}$ attributable to cell death over the first 3 postnatal weeks in the dorsomedial region of the mouse neocortex (Crandall and Caviness, 1984). The proportion of neuronal death in the neocortex, as estimated by direct cell counts (Leuba et al., 1977; Heumann et al., 1978) or by pyknotic cell counts (Finlay and Slattery, 1983; Finlay and Pallas, 1989), has ranged from 30 to $50 \%$. In these studies, cell death was judged to occur principally in the granular and supragranular layers rather than in layers $\mathrm{V}$ and VI. Thus, the significant but relatively low level of cell death 

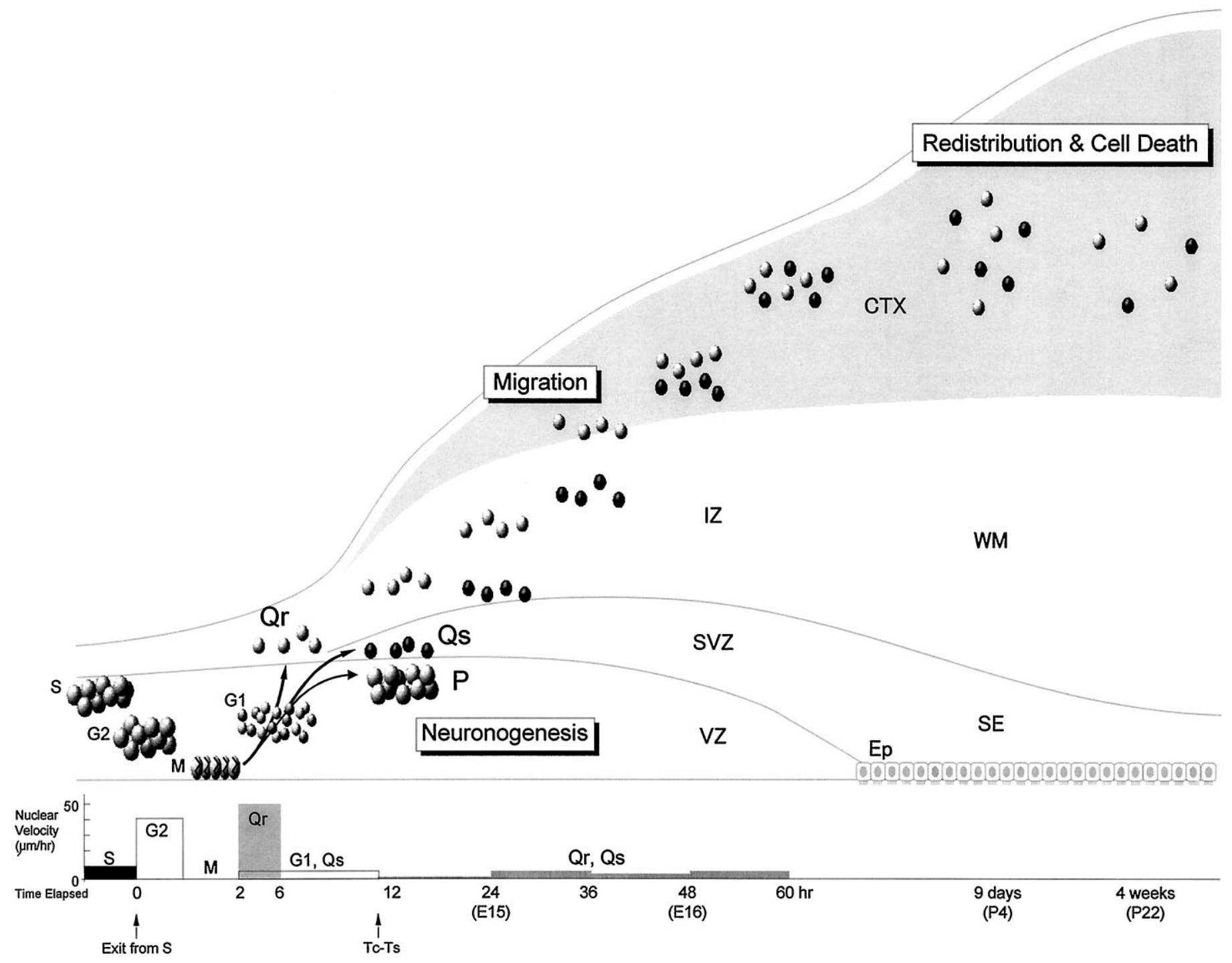

Figure 13. Histogenetic life cycle of a strictly defined cohort of cells. A cohort of neurons arising over an interval of 1-2 hr on E14 in the dorsomedial murine neocortical PVE separates after mitosis into a Q fraction that has left the cell cycle and a P fraction that will continue to cycle (Neuronogenesis). The $\mathrm{Q}$ fraction, in turn, separates into rapidly exiting $\left(Q_{r}\right.$, light spheres) and slowly exiting $\left(Q_{s}\right.$, dark spheres) subpopulations. Once above the VZ in the SVZ and IZ, the two subpopulations migrate (Migration) at indistinguishable rates until the leading, or $Q_{\mathrm{r}}$, subpopulation of the cohort is slowed on entry into the cortex $(C T X)$. Once in the cortex and in the course of ascent to the outer margin of the CP, the two subpopulations totally overlap and become indistinguishable. Later, they come to lie deep to neurons arising at later dates and are moderately reduced in numbers by histogenetic cell death (Redistribution \& Cell Death). After neuronal migrations are completed, the IZ and SVZ are replaced by the cerebral central white matter (WM) and subependyma $(S E)$, and the PVE within the VZ is replaced by a cuboidal ependymal ventricular lining $(E p)$. Provided at the base of the diagram is a temporal profile of these events with the nuclear velocities for cells of the proliferative cycle in S, G2, M, and G1 phases, and VZ exit and migration velocities of $Q_{\mathrm{r}}$ and $Q_{\mathrm{s}}$ registered on the ordinate. The diagram is schematic both with respect to scaling of time and distances.

detected in the present study in layer $\mathrm{V}$ is generally in accord with observations based on quite different analytic methods.

\section{Prospectus}

The analysis has provided the unexpected observation that the neuronal output on early E14 is made up of two subsets of postmitotic neurons that are substantially different from each other in terms of their rates of exit from the VZ. These two subsets appear not to differ in terms of their migratory behavior, and they become intermingled within the cortex once migrations are completed. Future experiments may clarify whether the two VZ exit behaviors reflect significant neuronal class-related behaviors. We also have estimated the rate of neuronal migration across the cerebral wall and have exploited our unique quantitative data to estimate the contribution of cell death to the final numbers of neocortical neurons. Both estimates are in accord with others based on quite different methods by other investigators. Overall, we have used the primary parameters of cell proliferation (the growth fraction, cell cycle length, $\mathrm{Q}$, and the number of integer cell cycles occurring through the neuronogenetic interval) to develop a quantitative picture of cortical development (Takahashi et al., 1996). The coherency of the predictions supported by this model with observations of other investigators suggests that it will provide the basis for the development of an integrated and comprehensive picture of the sequential processes that make up cortical development beginning with cell proliferation, continuing with cell migration, and culminating with selection of the final 
numbers and classes of neocortical neurons in the mature neocortex (Fig. 13).

\section{REFERENCES}

Bayer SA, Altman J (1991) Neocortical development. New York: Raven. Berry M, Rogers AW (1965) The migration of neuroblasts in the developing cerebral cortex. J Anat 99:691-701.

Bisconte J-C, Marty R (1975) Etude quantitative du marquage radioautographique dans le systeme nerveux du rat. II. Caracteristiques finales dans le cerveau de l'animal adulte. Exp Brain Res 22:37-56.

Blaschke A, Staley K, Chun J (1996) Widespread programmed cell death in proliferative and postmitotic regions of the fetal cerebral cortex. Development 122:1165-1174.

Cai L, Hayes NL, Nowakowski RS (1993) Comparison of the cumulative labeling S-phase method and the percent labeled mitoses method in the developing cerebral cortex. Soc Neurosci Abstr 19:30.

Caviness Jr VS (1982) Neocortical histogenesis in normal and reeler mice: a developmental study based upon $\left[\left[{ }^{3} \mathrm{H}\right]\right]$ thymidine autoradiography. Dev Brain Res 4:293-302.

Chenn AJ, McConnell SK (1993) Characterization and time-lapse imaging of cell division and interkinetic nuclear migration in the ventricular zone. Soc Neurosci Abstr 19:862.

Chenn AJ, McConnell SK (1995) Cleavage orientation and the asymmetric inheritance of Notch 1 immunoreactivity in mammalian neuronogenesis. Cell 82:631-641.

Crandall JE, Caviness Jr VS (1984) Axon strata of the cerebral wall in embryonic mice. Dev Brain Res 14:185-195.

Del Rio JA, Soriano E, Ferrer I (1992) Development of GABAimmunoreactivity in the neocortex of the mouse. J Comp Neurol 326:501-526.

Edmondson JC, Hatten ME (1987) Glial-guided granule neuron migration in vitro: a high-resolution time-lapse video microscopic study. J Neurosci 7:1928-1934.

Fernandez V, Bravo H (1974) Autoradiographic study of the cerebral cortex in the rabbit. Brain Behav Evol 9:317-332.

Finlay BL, Pallas SL (1989) Control of cell number in the developing mammalian visual system. Prog Neurobiol 32:207-234.

Finlay BL, Slattery M (1983) Local differences in the amount of early cell death in neocortex predict adult local specializations. Science 219:1349-1351.

Fishell G, Hatten ME (1991) Astrotactin provides a receptor system for CNS neuronal migration. Development 113:755-765.

Gadisseux J-F (1995) L'Organisation et le role du systeme glial durant le developpement du Neocortex des Mammiferes. PhD Thesis, Université Catholique de Louvain.

Gadisseux J-F, Kadhim HJ, van den Bosch P, Caviness Jr VS, Evrard P (1990) Neuron migration within the radial glial fiber system of the developing murine cerebrum: an electron microscopic autoradiographic analysis. Dev Brain Res 52:39-56.

Heumann D, Leuba G, Rabinowicz T (1978) Postnatal development of the mouse cerebral neocortex. IV. Evolution of the total cortical volume of the population of neurons and glial cells. J Hirnforsch 19:411-416.

Hicks SP, D'Amato CJ (1968) Cell migration to the isocortex in the rat. Anat Rec 160:619-634.

Komuro J, Rakic P (1993) Modulation of neuronal migration by NMDA receptors. Science 260:95-97.

Lavdas A, Mione M C, Parnavelas J G (1996) Neuronal clones in the cerebral cortex show morphological and neurotransmitter heterogeneity during development. Cereb Cortex 6:490-497.

Leuba G, Heumann D, Rabinowicz T (1977) Postnatal development of the mouse cerebral neocortex. I. Quantitative cytoarchitectonics of some motor and sensory areas. J Hirnforsch 18:464-481.

Luskin MB, Shatz CJ (1985) Neurogenesis of the cat's primary visual cortex. J Comp Neurol 242:611-631.
McConnell SK, Kaznowski CE (1991) Cell cycle dependence of laminar determination in developing neocortex. Science 254:282-285.

Miller MW (1986) The migration and neurochemical differentiation of gamma-aminobutyric acid (GABA)-immunoreactive neurons in rat visual cortex as demonstrated by a combined immunocytochemicalautoradiographic technique. Brain Res 393:41-46.

Mione MC, Danevic C, Boardman P, Harris B, Parnavelas JG (1994) Lineage analysis reveals neurotransmitter (GABA or glutamate) but not calcium-binding protein homogeneity in clonally related cortical neurons. J Neurosci 14:107-123.

Nowakowski RS, Rakic P (1979) The mode of migration of neurons to the hippocampus: a Golgi and electron microscopic analysis in fetal rhesus monkey. J Neurocytol 8:697-718.

O'Rourke NA, Dailey ME, Smith SJ, McConnell SK (1992) Diverse migratory pathways in the developing cerebral cortex. Science 258:299-302.

Parnavelas J, Barfield JA, Franke E, Luskin MB (1991) Separate progenitor cells give rise to pyramidal and nonpyramidal neurons in the rat telencephalon. Cereb Cortex 1:463-468.

Rakic P (1974) Neurons in rhesus monkey visual cortex: systematic relation between time of origin and eventual disposition. Science 183:425-427.

Rakic P, Stensaas LJ, Sayer EP, Sidman RL (1974) Computer aided three-dimensional reconstruction and quantitative analysis of cells from serial electron microscopic montage of foetal monkey brain. Nature 250:31-34.

Rakic P, Cameron RS, Komuro H (1994) Recognition, adhesion, transmembrane signaling and cell motility in guided neuronal migration. Curr Opin Neurobiol 4:63-69.

Schwartz ML, Meinecke DL (1992) Early expression of GABAcontaining neurons in the prefrontal and visual cortices of rhesus monkeys. Cereb Cortex 2:16-37.

Sidman RL, Rakic P (1973) Neuronal migration, with special reference to developing human brain: a review. Brain Res 62:1-35.

Sidman RL, Miale IL, Feder N (1959) Cell proliferation and migration in the primitive ependymal zone: an autoradiographic study of histogenesis in the nervous system. Exp Neurol 1:322-333.

Takahashi T, Nowakowski RS, Caviness Jr VS (1992) BUdR as an S-phase marker for quantitative studies of cytokinetic behaviour in the murine cerebral ventricular zone. J Neurocytol 21:185-197.

Takahashi T, Nowakowski RS, Caviness Jr VS (1993) Cell cycle parameters and patterns of nuclear movement in the neocortical proliferative zone of the fetal mouse. J Neurosci 13:820-833.

Takahashi T, Nowakowski RS, Caviness Jr VS (1994) Mode of cell proliferation in the developing mouse neocortex. Proc Natl Acad Sci USA 91:375-379.

Takahashi T, Nowakowski RS, Caviness Jr VS (1995a) The cell cycle of the pseudostratified ventricular epithelium of the murine cerebral wall. J Neurosci 15:6046-6057.

Takahashi T, Nowakowski RS, Caviness Jr VS (1995b) Early ontogeny of the secondary proliferative population of the embryonic murine cerebral wall. J Neurosci 15:6058-6068.

Takahashi T, Nowakowski RS, Caviness Jr VS (1996) The leaving or Q fraction of the murine cerebral proliferative epitheium. J Neurosci, in press

Van Eden CG, Mrzljak L, Voorn P, Uylings HBM (1989) Prenatal development of GABAergic neurons in the neocortex of the rat. J Comp Neurol 289:213-227.

Waechter RV, Jaensch B (1972) Generation times of the matrix cells during embryonic brain development: an autoradiographic study in rats. Brain Res 46:235-250.

Windrem MS, Nowakowski RS (1993) Developmental increase in the proportion of cells leaving the proliferative zones during the generation of neocortex. Soc Neurosci Abstr 19:29. 